\title{
ENACTING ETHNICITY OF "JAPANESE CANADIAN" IN ORAL HISTORY: A COMPARISON BETWEEN THE JAPANESE CANADIAN SANSEI AND THE IJUSHA NISEI
}

by

Kawai Shunya, Bachelor of Arts, Kyoto University, 2015

A Major Research Paper

Presented to Ryerson University

In partial fulfillment of the requirements for the degree of

Master of Arts

In the Program of

Immigration and Settlement Studies

Toronto, Ontario, Canada, 2016

(C) Kawai Shunya 2016 


\section{Author's Declaration}

I hereby declare that I am the sole author of this MRP. This is a true copy of the MRP, including any required final revisions. I authorize Ryerson University to lend this MRP to other institutions or individuals for the purpose of scholarly research. I further authorize Ryerson University to reproduce this MRP by photocopying or by other means, in total or in part, at the request of other institutions or individuals for the purpose of scholarly research. I understand that my MRP may be made electronically available to the public. 


\title{
ENACTING “JAPANESE CANADIAN” IN ORAL HISTORY \\ —A COMPARISON BETWEEN JAPANESE CANADIAN SANSEI AND IJUSHA NISEI
}

\author{
Kawai Shunya \\ Master of Arts 2016 \\ Immigration and Settlement Studies \\ Ryerson University
}

\begin{abstract}
This paper presents the non-essentializing analysis of ethnic identity formation in comparative research between two groups in the Japanese Canadian community: the Japanese Canadian Sansei and the Ijusha Nisei. Using an oral history approach to understand the development of ethnic identity, I discuss how the social assignment of "otherness" based on the corporeal difference has negatively influenced identity formation in both groups. My comparative analysis further uncovers some of the different strategies that each group takes against the racializing process. Whereas the Japanese Canadian Sansei claim their cultural citizenship in the history of Japanese Canadians by aligning their own personal past with the collective memory of Japanese Canadians, the Ijusha Nisei negotiate it by entitling themselves as a contemporary representative of the ideology of multiculturalism. Finally, understanding the different processes of ethnic identity formation and strategies of negotiation for social inclusion, I discuss the effects of the ideology of multiculturalism on cultural citizenship among Japanese Canadians.
\end{abstract}

Key Words: Japanese Canadian; collective memory; ethnic identity; culture; oral history 


\section{Acknowledgements}

First and foremost, I cannot be thankful enough to my supervisor, Dr. Pamela Sugiman, for navigating me throughout the project from the very beginning to the very end. Without her encouraging comments and insightful advice, I could not welcome this proud moment. Then, I would like to extend gratitude to the second reader, Dr. Amina Jamal. Her expertise led me to the more in-depth and critical discussion.

Second, I present sincere gratitude towards all the people involved in this research project, including the people who helped me to reach out to the potential participants, the people who showed the interest in my research, and the participants in this research. Their willing cooperation encouraged the nascent researcher to follow through all the processes of this research project within the strict timeline. In addition, their expression of hospitality enabled me to enjoy the interview and energized me to tackle the hardships of writing the MRP.

Finally, I mention my family and friends who constantly gave great help to motivate me. In particular, my parents were committed to indescribably tremendous help. It is unimaginable how much my parents were concerned about my "untypical" choice to go abroad to study more. Despite a sense of uncertainty, they kept showing respect of my choice and encouraged me on every occasion where we had a chance to talk. Although I don't think saying thank you here can adequately respond to their enduring patience and considerable understanding, but let me express the greatest gratitude that I can do. I thank you so much for everything you have given to me. 
Table of Contents

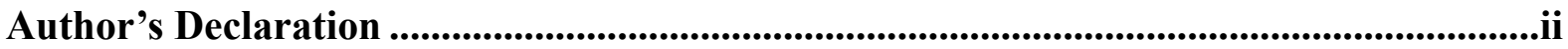

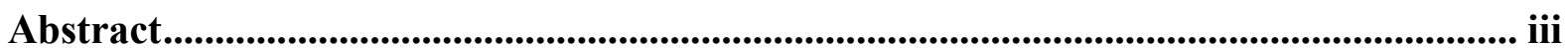

Acknowledgements ........................................................................................................................................iv

Introduction ...............................................................................................................................................1 1

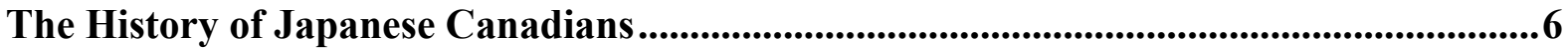

The Arrival of the First Japanese Immigrant and Racialization of Japanese immigrants.......................6

The Outbreak of the WWII and the Sequential Uprooting .........................................................................10

The Second Uprooting and Sansei's Social Background .......................................................................13

New immigration from Japan and Ijusha Nisei's social background .......................................................19

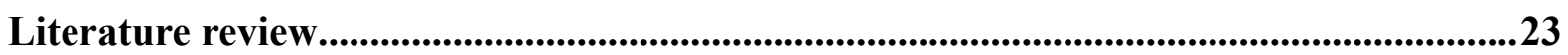

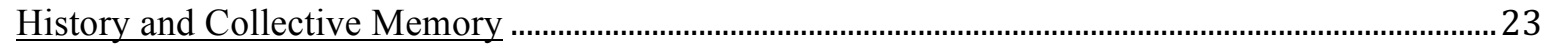

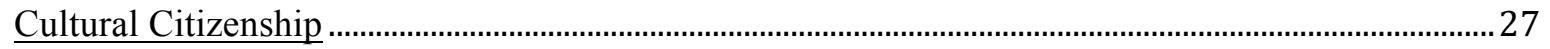

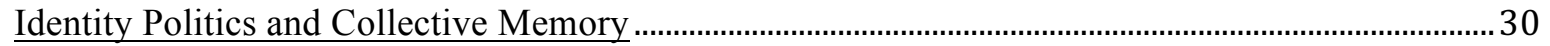

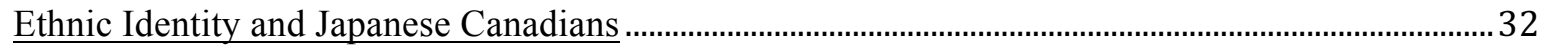

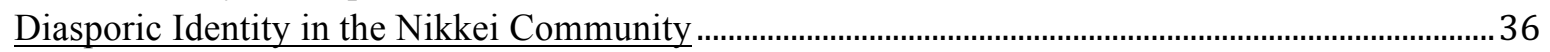

Methodology .............................................................................................................................................38

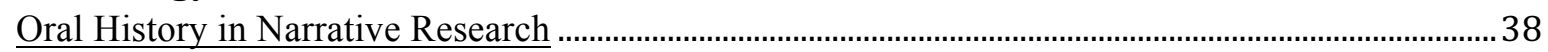

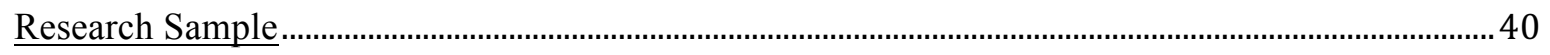

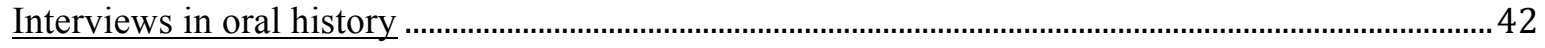

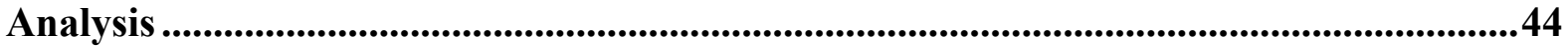

Japanese Canadian Sansei: To be aware of being Japanese Canadian ..................................................... 44

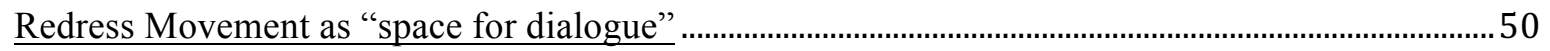

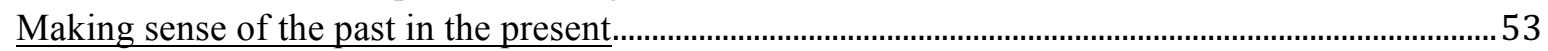

Ijusha Nisei: Visibility as Japanese and becoming Canadian ................................................................57

Social Assignment of "otherness" and the self as a representative of multiculturalism .......................64

Reifying myself as the subject of interview...................................................................................68

Japanese Canadian food: Connection to the past and assimilated self....................................................69

Bridge between the Ijusha Issei and the Ijusha Nisei ............................................................................. 71

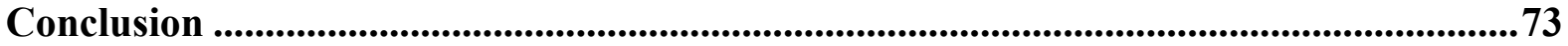

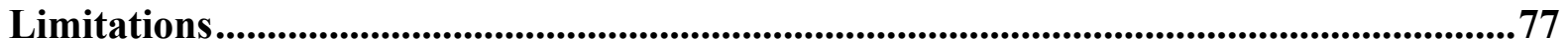

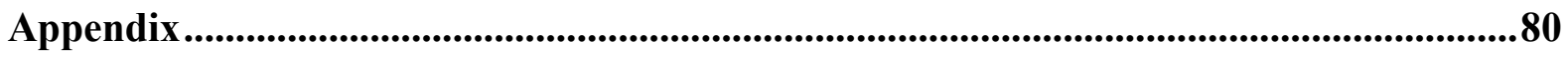

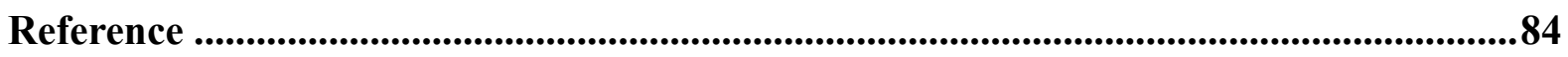




\section{List of Table}

Table 1: Profile of Interview Participants 


\section{Introduction}

Ethnicity is a social construct. The surging postmodernist's viewpoint in social science, which critiques how the power of representation can be explained in the process of internalization, transformation, and enactment of social, cultural, and historical knowledge, transformed ethnicity into the discussible space beyond essentialization. Throughout this research project, my understanding of ethnicity has come to be informed by Hall's (1996:445) discussion of "new ethnicities". Aware of "the deep ambivalence of identification and desire" that negates the "fixed selves" that construct identity, he remarks that "the term ethnicity acknowledges the place of history, language, and culture in the construction of subjectivity and identity, as well as the fact that all discourse is placed, positioned, situated, and all knowledge is contextual" (p. 447). Compared to this definition of ethnicity, race is embodied as a bodily reality that is socially and historically constructed and institutionalized by a transcendent essentializing force beyond time and space. Whereas ethnicity is the contextual knowledge that accordingly holds "hybridity" in its epistemological discussion of identity and subjectivity, intersected with other attributions such as citizenship, nationality, skin color, gender, language, and culture, this essentializing force of race legitimates the aspiration for the control based on this bodily difference and perpetuating the domination of the body politics that marginalizes people of colour.

Additionally, ethnicity is not a static attribute of human beings that exists independent of individual lived experiences. Rather, it is incessantly (re)constituted and enacted in individual everyday lives and communications. Hall's understanding of ethnicity untangles "codes" inscribed in these mundane interactions. These codes emerged in a particular time and space and has been maintained by "a history" as a discursive space. Particularly, the ethnic identity of Japanese Canadians has been discussed around the interpretation of their 
traumatic past in Canada with its focus on seemingly contradicting two notions, "assimilation" and "multiculturalism", as forms of the negotiation against the racialization of Japanese Canadians. This research project found these two ideas are still influential to the ethnic identity formation of the current Japanese Canadians who did not have direct experience of the internment, dispossession, and dispersal of persons of Japanese origin. Since the historical aspect of ethnicity has urged Japanese Canadians at present to contextualize the discursive knowledge of "assimilation" and "multiculturalism" in their life course, the representation of ethnicity of Japanese Canadians goes back and forth between the past and the present. With the oral history approach, this research project is intended to explore how the Japanese Canadians at present shape their lived experiences and narration of the past as forms of the negotiation for social inclusion in the process of ethnic identity formation in which they internalize and reconstitute notions of "assimilation" and “multiculturalism”.

In this research study of Japanese Canadians, I conducted oral history interviews with two groups who were born after WWII and thereby did not directly experience the internment, dispossession, and dispersal of persons of Japanese origin. The first group is the Japanese Canadian Sansei ${ }^{1}$, whose grandparents immigrated to Canada in the late 19 th or the early 20th centuries and whose families have the subjective experiences of the historical injustice during WWII. These traumatic memories of their parents, the Japanese Canadian Nisei, disrupted the intergenerational transfer of Japanese cultural heritage and memories of

\footnotetext{
1 The particular experience during WWII explains the specific usage of Japanese words that delineates the generational line such as Issei (first-generation), Nisei (second-generation), Sansei (thirdgeneration), Yonsei (forth-generation). That remaining custom within the community indicates the specific meaning attached to the generational line beyond just an order of generation. In this research, I, on purpose, use these Japanese words to indicate these associations that Japanese Canadians have constructed throughout the history and participants reproduced in their narration.
} 
the historical injustice, prompting the Japanese Canadian Sansei assimilate in the white Anglo-Saxon culture in Canada. On the other hand, as the Redress movement came to a head of the Canadian politics in the late 1970s, this loss of the cultural and historical connection surged as an epitome of violence of the state and the rediscovery of this connection was explored based on the civic cultural rights that the ideology of multiculturalism presented to the public.

The other group is the Ijusha Nisei, whose parents immigrated to Canada years after WWII. Those who immigrated to Canada after WWII are called Ijusha, which literally mean "immigrant" in the Japanese language. Most of their parents immigrated to Canada through the "point system" that favored immigrants with higher financial and human capital. Unlike the Japanese Canadian Sansei, no one in their families have the direct experience of the historical injustice and thereof feel cultural and historical detachment to the earlier Japanese Canadian community. They inherited Japanese culture and values from their parents in the familial environment where they were raised up. These conditions grew a different sense of ethnic identity as Japanese Canadian, driving them to take another path to negotiate social inclusion on an occasion where their social rights as Canadian citizens are denied based on the physical appearance.

In these explorations, I highlight two major points that emerged from the oral history interviews. First, I wish to address how Japanese Canadians, differently located in the social, cultural and political terrain of Canada, have negotiated their ethnic identity by enacting ethnicity in their lives under the ongoing racialization of Japanese Canadians. The oral history approach, which is not intended to generalize the historical understanding of ethnic identity, reveals the process of Japanese Canadian Sansei's internalization of the collective memory of the historical injustice in individual accounts and its role in identity formation. Whereas acknowledging the political utility of the uniformed public history of Japanese 
Canadians, I caution against the colonialization of the individual agency with which Japanese Canadians construct the ethnic identity based on diverse experiences. This agency over their own narratives shapes their experiences as a source of resistance against the racialization of Japanese Canadians.

The predominant focus on the group of Japanese Canadians whose families directly connect their experience to the historical injustice have occupied academic and public discussions, leaving a communal divide within the Japanese Canadian community. Addressing this issue, the comparative analysis highlights that the Ijusha Nisei take a different strategy for the negotiation of social inclusion and enact ethnicity through the ethnic identity formation based on the different understanding of the multiculturalism constructed in their lived experiences. The discovery of the different strategies between the Japanese Canadian Sansei and the Ijusha Nisei of the negotiation for social inclusion informs the effects of multiculturalism on cultural citizenship among Japanese Canadians.

Secondly, I argue that people's oral narration is more than just a recollection of objective past events. It is also a representation of their ethnicity. Thinking back to Halbwachs's writings on collective memory, we understand that narrating the past is influenced by the social conditions of where and when the memory is narrated. Narrators attempt to make sense of the past in the present condition. Drawing on this perspective, I argue that the narration itself is an enactment of ethnicity and throughout their narrations, people utilize resources that they can leverage to construct and perform their ethnicity by selecting their lived experiences. Acknowledging this performativity of memory, we can reach out to their interpretations of social inclusion and exclusion, using particular codes, "assimilation" and "multiculturalism". In addition, this understanding of the narration enables me to recognize my involvement in the oral history project as a co-constructor. The firstperson "I" who has specific experiences, not the third-third person detached researcher, is 
reified in the narration as a resource to construct their accounts of the past. Positing me in their conceptualization of ethnicity, the narrators in this study perform their ethnicity through their personal narratives of the past.

This particular nature of the oral history approach that reifies my experiences in my oral history interviews requires that I reveal my own experiences and relationship to this research. As an international student who came to Canada last year (2015), I felt alienated in the city of Toronto because I could not find a pocket that I was able to fit in and also because I could not express myself in English well. In the mosaic city that contains diverse cultures, I was buried in the intimidating sense of multiculturalism that required me to stand out as "Japanese". This prompted me to start looking for the Japaneseness that defines me and also that I am presenting to the world at large. In the process of self reflection, I came to be involved in both the Japanese Canadian community and the Ijusha community. Being exposed to the open-minded atmosphere of each, I felt my own in-between status; on the one hand, I missed Japan as the place to which I felt belonging and on the other, I am urged to make sense of my decision to leave the country albeit, so far, still temporally. I internalized the differences between Canada and Japan in cultural, social, gender, and racial norm differences that they mention to legitimate their sense of belonging to Canada in comparison to that to Japan - and provide my own experiences concerning with those differences. Sharing these experiences, in some cases, recalled distressing and bitter memories. In a somewhat uncomfortable way, my involvement in oral history interviews piqued my sense of belonging to Japan and urged the narrators to use me as a symbol of "otherness".

Before discussing the theoretical foundation of this research, I present the following section on the historical background of the immigration of the Japanese in the late 19th century, leading to the social environments in which Japanese Canadian Sansei were raised. For the purposes of this study, I highlight the widespread ideology of assimilation and the 
emergence of the ideology of multiculturalism that defined their early lives. The description of history explains the genealogy of the ideology of assimilation and multiculturalism within the Japanese Canadian community.

Additionally, the awareness of the existence of distinct groups that have Japanese diasporic ties in common directs the researchers' attention to the maintenance of the cultural heritage by defining the Japanese diasporic community subsuming both groups. This type of research introduces a new ethnic category "Nikkei". According to the Association of Nikkei and Japanese Abroad (2016), Nikkei "refers broadly to Japanese people who have relocated overseas on a permanent basis, as well as their second, third and fourth generation descendants, irrespective of current nationality and degree of Japanese ethnicity". Although this type of research assumes a centripetal power of the imagined homeland that unites the people having Japanese roots, significantly different immigration experiences demonstrated the emergence of the Ijusha community as a distinctly different group from the earlier Japanese Canadian community that had already existed. These different experiences of Ijusha community are shaped by challenges happening in their settlement processes and hopeful expectations of a life in Canada mostly constructed as a counterpart of a sense of disappointment, stagnation, and impasse in Japanese society. By providing the information of the different experiences that expands the horizon of our thinking about "people of Japanese descent", I attempt to arrange the rudimentary basis on which the comparative analysis on the ethnic identity as Japanese Canadian is conducted between the Japanese Canadian Sansei and the Ijusha Nisei.

\section{The History of Japanese Canadians}

The Arrival of the First Japanese Immigrant and Racialization of Japanese immigrants

The first Japanese immigrant, Manzo Nagano, landed in British Columbia, Canada in 1877. Like most immigrants, the Issei came to this country with aspirations for better jobs 
and thus improved. In most cases, the Issei voyaged to Canada relying largely on familial and community networks. Leaving behind many intimate relationships and still feeling a sense of belonging to their hometown, they started to build a new community in Canada in a way that loosely replicated a social characteristic of that in their hometowns such as local fishing towns and agricultural villages. The construction of ethnic enclaves grew as the population of Japanese immigrants increased during the 1890 s and the 1900 s. As a result, by $1941,95 \%$ $(22,096$ out of 23,149$)$ of Japanese Canadians lived in British Columbia (Iino, 1985). The imitated systems enhanced community solidarity as an autonomous force that helped to provide social, human, and financial capital and protected the Issei and their offspring, the Nisei from the racism against them and the exploitation of low-wage labour. This somewhat self-sufficient community was targeted as the representation of racial "otherness" and thought to confirm the essentialized subject, inassimilable in Canada.

The racialization of Japanese Canadians should not be regarded simply as the compound of individual xenophobic reactions to their concentration on this country's west coast. The anti-Japanese sentiment created and at the same time was exacerbated by structural barriers that were already embedded in Canadian society. On the one hand, the massive influx of low-wage labour from Japan between the end of 19th century and the beginning of 20th century was welcomed by capitalists in British Columbia, and encouraged by the federal government's policies. On the other hand, the middle working-class population expressed concerns that their already low wages and poor working conditions were exacerbated by immigrants' willingness to work in inferior working conditions at equally low, if not lower wages. As Marxist scholars of work have long established (Goutor, 2007), this hierarchization of labour was beneficial to capitalists as it weakened the bargaining power of the white male middle working-class. 
The concentration of Japanese Canadians on ethnic enclaves such as "Japantown" in Vancouver, Mission City and Fraser Valley villages in Steveston, and Tofino and Prince Ruper in Powell River, was understood as the proof that they were unassimilable in the white, European Western society. This anti-Japanese notion was intensified by not just the fear of downgrading of "the morality of civilians" derived from the immigrants" willingness to work in the poorer working and living conditions but also the labourers' concerns of uncertainty because of the severe recession in the mid-1890s (Goutor, 2007). These factors lead to the legitimation of racist anti-Asian stereotypes, epitomized by the "yellow peril".

According to this racist discourse, Japanese Canadians were "dishonest, unclean, immoral, and unable to assimilate" to Canadian society (Kelley \& Trebilcock 1998, p. 146). Izumi (2008) gives a critical analysis of the racist discourse from the perspective of white supremacism. According to him, this racist thinking was also spurred by the middle workingclass whites' frustrations. In those days, the first objective of the white British gentlemen who immigrated to British Columbia was to imitate the British lifestyle. Against their expectations, a large number of "strange" Asian immigrants settled in British Columbia. The concentration of Asian immigrants demonstrated the failure to construct the white society in the west coast, creating a sense of being marginalized from the mainstream white community in Europe or the east coast of North America. He argues that these accumulated frustrations were also funneled to the racist movement excluding Asian immigrants from British Columbia and rebuilding "ideal" white community.

Such racist discourse was both fuelled and given legitimacy by Canadian judicial, legal, and administrative institutions. In particular, the provincial government of British Columbia took severe measures towards immigrants from Asia. From 1872 to 1922, the provincial government of British Columbia proposed over 100 laws that discriminated against Japanese and Chinese immigrants, although most of them were ultimately revoked by 
the federal government (Kelley \& Trebilcock, 1998, p. 99). Yet despite conflicts between the federal and provincial government, some of these anti-Japanese laws were implemented.

For example, Japanese Canadians owned about half of fishing licenses in British Columbia in 1919. In reaction to complaints from white West-Coast fishermen, the Department of Fisheries restricted Japanese fishermen's operations and stripped 1,000 fishing licenses of Japanese Canadians by 1925 (Omatsu, 1992, p. 58-59). Another example is that the legislature of British Columbia denied the franchise to those of Japanese and Chinese descent in 1895. This removal of Japanese and Chinese men from the voters' list in the province meant the loss of the right to vote in the federal election according to the legal system in those days (Kelley \& Trebilcock 1998, p.146-147). In 1931, the lobbying of Japanese Canadian male veterans who served military during the First World War retrieved the suffrage. But this right was limited only to Japanese Canadian male veterans and the vote rights of female Japanese Canadians were not entitled, nor even discussed as a main issue. (Dick, 2010).

The anti-Japanese racism of these kinds came to a head in a riot in Vancouver in 1907, elicited by a rally by the Asiatic Exclusion League in Vancouver, which espoused "White Canada" (Izumi, 2008). Immediately after this riot, reversing the previous pro-immigration policies, the federal government established "gentleman agreements" with the Japanese government. Such agreements rested on the Japanese government's voluntary restriction of the number of Japanese emigrants to Canada to under 400 per year.

Since then, restrictions on Japanese immigration to Canada followed in reflection of fueled anti-Japanese sentiments. As the following series of amendments to the immigration policy limited the incorporation of immigrant labour from Japan, the demographic profile of Japanese immigrants had changed from young male labourers to young females who were 
migrating to Canada for family reunification or marriage arrangements. The influx of female immigrants is one of the important factors for the settlement of Japanese Canadians who longed for the return to Japan, although this feminization of the Japanese immigration, epitomized by the "picture bride" migration, introduced gender inequality to the family decision-making process in the Japanese Canadian community. (Izumi, 2013; Oharazeki, 2013).

In this increased anti-Japanese racism in the west coast, WWI took place. Male Japanese Canadians volunteered the military services to demonstrate their loyalty to Canada. Although the dedication of Issei's and Nisei's life to the Canadian military services was expected to alleviate this racial discrimination, the racist talks and thoughts were not ebbing, and rather this stagnation was all the more distressing to Japanese Canadians (Dick 2010). It is also important to note that the way to demonstrate loyalty to Canada was limited to the male who made the commitment to the military service. Sugiman (2009) remarks, this is the reflection of the gendered subjectivities of racial minorities in relations to the national belonging in the history.

\section{The Outbreak of the WWII and the Sequential Uprooting}

The anti-Japanese sentiment came to a peak at the outbreak of World War II. As soon as the Japanese navy attacked the Pearl Harbor on December 7, 1941, Japanese Canadians became in danger of the culminated racism. On the very same day, 38 people were arrested and jailed. Newspaper companies and Japanese schools were closed in the wake of fear that they were plotting espionage or sabotage. Assets in companies owned by people of Japanese descent were frozen and personal and organizational property were confiscated. The property appropriated by the government ranges from automobiles, fishery vessels, houses, farming lands, and to personal belongings signaling some connection to Japan. The confiscated property was administrated under "protective custody", liquidated by an Order-in-Council on 
January 19,1943 , and sold at unfairly underestimated prices. The earned money was used to pay the costs involving in running "concentration camps" and modest remnant money was sent to the property owners (Marsh, 2012). This groundless fear of "enemies inside Canada" was accredited by the government's declaration in the Order-in-Council issued on December 17, 1942, which labeled Japanese Canadians as "enemy aliens" regardless of their citizenship and place of birth.

On February 24, 1942, then Prime Minister W. L. Mackenzie King passed a series of exclusion acts that banished "people of Japanese race" from the west coast into the interior of British Columbia. These were euphemistically called "protective areas", which is a 100-mile wide belt along the west coast. Oikawa (2012) argues that the euphemistic language, such as "protective areas or custody", "evacuation”, and "dispersal of Japanese Canadians for their safety", was used purposefully to justify the violation of human rights and opportunistic exploitation of the assets of Japanese Canadians. In this "liberal" construction of history, she argues that the government took advantage of the image of Japanese Canadians that represented the ideal subject-citizen relationship. Under this "liberal" mask of the history, over 22,000 "people of the Japanese race" were forced to leave their homes in that "protective areas" despite the fact that 13,309 out of them had Canadian citizenship by birth (Marsh, 2012).

The internment of Japanese Canadians separated families. Capable men were sent to road camps in Ontario and the border between British Columbia and Alberta. Women and children were interned in other places in the interior of British Columbia. Here, they were forced to live in gloomy and untamed shacks partitioned by a thin wooden board covered with papers coated in flimsy layers of tar. Besides, most letters from "internment camps" were censored by the British Columbia Security Commission. In late 1943, because of a scarcity of farm labour, about 3,000 families were sent from the "internment camps" to sugar 
beet farms in Alberta and Manitoba (Fujiwara, 2012). Although these people were allowed to live with their family members, the widespread racism marginalized these Japanese Canadian farmers such as the oppression from the Alberta Sugar Beet Growers' Association (see Fujiwara, 2012).

Even as the war was coming to an end, injustice towards Japanese Canadians continued. In excuse of protecting Japanese Canadians from a fierce backlash, the federal government prohibited Japanese Canadians from returning to British Columbia until 1949. In the meantime, the government issued another order with the euphemistic rhetoric that forced Japanese Canadians to "voluntarily" choose whether "repatriate" to Japan or relocate beyond the Rocky Mountains. In those days, most Nisei and Sansei had never been to Japan. Noting this fact, Sugiman (2006) critically discuss the government's implications of wording "repatriate". The forced "repatriation" to the country they had never stepped on despite their jus sanguinis citizenship in Canada demonstrates another political accomplice to racism against Japanese Canadians. Faced with the "voluntary" choice out of the limited options in the condition where the communication among family members were geographically and politically constrained, they had to make the decision. Nearly 10,000 signed to leave for Japan, many of them under the belief that their decisions could be changed after signing. Although this order was revoked in 1947, 4,000 Japanese Canadians had already left Canada by the time (Kobayashi, 1992).

McKenzie King's Government supported the dominant view that the resettlement of Japanese Canadians and even hostility against them was a "Japanese problem" caused by their inassimilability. King relentlessly argued, "[t]he sound policy and the best policy for the Japanese Canadians themselves is to distribute their members as widely as possible throughout the country where they will not create feelings of racial hostility" (Canada, House of Commons 1994, 5917 cited by Makabe, 1998, p.23). Many Japanese Canadians found it 
difficult to recover their past lives in British Columbia because of the ongoing harsh racism and the loss of their material assets. Therefore, many heeded the governmental order and ventured eastward to demonstrate their "loyalty" to the nation even after the "100-miles protective area" order was canceled (Sugiman, 2006).

After WWII and their unjust dispossession and displacement, Japanese Canadians were faced with huge economic challenges. After all, they had lost their employment and all of their accumulated assets, albeit modest for most. Many of the Nisei who had been studying in post-secondary institutions before the war had to give up further education because of the wretched financial status of their families compounded by continued racial discrimination. In addition to these material and opportunity losses, the deprivation of dignity and self-esteem as Canadian civilians were so devastating that this experience was deeply inscribed in their memory. This traumatic memory influenced how the Japanese Canadians resumed their "new" life in an unfamiliar environment.

\section{The Second Uprooting and Sansei's Social Background}

In newly settled homes, the Issei and Nisei were reluctant - actually did not have any choice - to establish ethnic enclaves like those they had in British Columbia. This is because the idea that the establishment of ethnic enclaves was a cause of social hostility towards people of Japanese descent and "disloyal" to the nation that - although its intention was euphemistically conveyed by the state- offered a "chance" for Japanese Canadians to assimilate into the Canadian society, was propagated by the state and also internalized by Japanese Canadians. This pro-assimilationist attitude was also found in a community newspaper before WWII to negotiate Japanese Canadian citizenship in Canada. The New Canadian, which was the only community newspaper that was allowed to be published during WWII, criticized the invocation of the citizenship of Japanese Canadians by depicting them as a white woman in a caricature (Sarkowsky, 2008). This community newspaper was 
the only way for Japanese Canadians during the wartime to obtain information about lives after the relocation and settlement, and economic conditions of the uprooted Japanese Canadians. The importance of community media in terms of uniting Japanese Canadians remained - ones might argue increased - after the community was dispersed because of the wartime measure. In addition to New Canadian, some community newspapers - one of the most popular newspapers was Tairiku Jiho (Continental Times) - were published to inform the community news and cultural events. These community newspapers were one of a few ways to know about lives of their ethnic cohorts and opportunities to be involved in the cultural expression in their new life as "Canadians" where they did not have daily contacts with other Japanese Canadians.

Some scholars (Miki, 2004; Makabe, 1998) note that the attitude towards assimilation was internalized and practiced by some Japanese Canadian organizations, families, and individuals. For example, the Cooperative Committee on Japanese Canadians, which was mostly made up of the Nisei, held an assumption that "the dispersal and assimilation of the Japanese Canadian community would solve the racial problems encountered in British Columbia" (Miki, 2004, p. 128). Others point out that this attitude should be understood in the desperate social and economic conditions of Japanese Canadians. In that sense, they were primarily concerned about rebuilding their shattered lives and starting a "new life" as a "full-fledged Canadian" based on the 1949 Order that entitled them citizenship again, and thereof feared any possible hindrances that might inhibit this return back to their "usual" life (Kobayashi, 1992).

This conceptualization of a "Canadian life" is one of the most prominent themes that has delineated the lives of Japanese Canadian Sansei. According to Makabe (1998), deprived opportunities to education and professional occupations shaped the Nisei's high educational expectations for their Sansei children and contributed to the Sansei's high educational 
achievements. Albeit, as Oikawa (2012) reminds us, not all Sansei experienced upward economic mobility.

The exploration of assimilated lives was seen in geographical settlement patterns, for instance. Along with the Government's attempts to scatter Japanese Canadians "far and wide," many Japanese Canadian families purposely moved to white neighborhoods where no other Japanese Canadians lived (Makabe, 1998). In the neighbourhood, they refrained from getting together in the public space and stopped using the Japanese language, even at home. This forced assimilation process of Japanese Canadians caused a huge cultural loss and described as the "silent" and "fragment" history by Sansei scholars and writers (Sugiman, 2004). Reflecting on "an erosion of human dignity, and a dramatic disruption of personal lives and family relationships", Sugiman (2004) calls this demolition of cultural heritage "cultural genocide".

It is the redress movement in the late 1970s that played an important role in the reformation of a Japanese Canadian community. The political movement against the government's past injustices had been somewhat dormant during the 1950s and 1960s because of its "radicalism" aura (Kobayashi 1992). However, the community concern that the aging Issei's population were disappearing, urged the Japanese Canadian community, especially Sansei professionals, to take an initiative for political action (Omatsu, 1992). At the 100th anniversary ceremony celebrating the day of the first Japanese arriving in Canada, the idea of the redress surfaced in a more concerted manner. The basic claim of redress was the official acknowledgement of the historical injustice and modest financial compensation for individual Japanese Canadian internees and the Japanese Canadian community.

Remembering her involvement in the redress movement, Omatsu (1992, p. 39), a Sansei lawyer, confessed in her book Bittersweet Passage that she understood her inherited 
"shame" despite the Nisei's good intentions to protect their children from the insidious past. She remarks that while she herself understood Nisei parents' silence, Sansei children were cut off from the ancestral ties; her Japanese Canadian body in the white neighborhood reminds her that "an alien blood flowed in [her] vein."

Conflict deriving from generational differences can be observed on the community level as well. Omatsu further describes "afraid of backlash, frightened to criticize authority, avoidant of real democracy, the [National Japanese Canadian Citizens' Association (NJCCA)] simply reflected the ever-present community nightmare of a resurgence of racism” (p.95). This attitude was epitomized in much of the scholarly and popular literature as "shikataganai (it-can't-be-helped)" or "bless in disguise" discourse. By leaving the past behind out of their control and focusing on their current "good" lives, or even ascribing the "good" lives to the forced relocation, Issei and Nisei survivors attempted to normalize the historical and political injustice. Makabe (1998) remarks that this "defensive" attitude seems to the Sansei - who structurally and psychologically achieved "full-scale assimilation" into the Anglo-Canadian culture and went through the socialization process where they learned the "real democracy" to "immobilize" the Japanese Canadian community.

These different interpretations called for the reconciliation of the interpretation of the historical injustice and the ensuing cultural amnesia beyond generational lines. The Japanese Canadian Sansei raised their voice on behalf of the Issei and Nisei against the state that invocated the human fundamental rights during the war. But the lack of direct memories of the intimidating historical injustice and the gap of the historical knowledge between the Nisei and Sansei caused a backlash from the Issei and Nisei community, posing a question into the objective and legitimacy of the Redress movement led mainly by the Japanese Canadian Sansei. The process of reaching a consensus of the objective of the Redress movement was advanced by creating more community space where Nisei's memories were exchanged with 
and narrated to the next generation and heightening the ethnic identity as Japanese Canadian, not just as Canadian, in the Sansei population.

The National Association of Japanese Canadians (NAJC), which was the renamed organization from NJCCA for the Redress movement, first started to rebuild a nationwide communication network of the geographically dispersed Japanese Canadian community. This reconstruction of the scattered community was attempted through a wider readership of two nationwide community newspapers, the New Canadian and Tairiku Jiho (Continental Times), and NAJC's own paper, NAJC News. Wider circulation of these newspapers aimed at "educating" both generations about the tenet of the Redress based on the community's responsibility to the past and the present.

In order to make the generation-bridging conversation reaching the consensus for the Redress, the NAJC also founded the sodan-kai. The sodan-kai was a group that held a series of public meetings, open forums, and house meetings to reconcile shikataganai attitudes, which criticized the Redress as "too militant, too greedy, and too revengeful," with the NAJC's Redress strategy team that was mostly composed by Sansei professionals. The latter group was leading the call for individual monetary compensation, an anti-racism agenda, and civil rights protection for all Canadians (Omatsu, 1992).

What the Japanese Canadian community had to overcome was not only in-group tensions and negotiations, however. In addition, it had to reconstruct the relationship of the Japanese Canadian community to the Canadian general public, beyond the ethnic boundaries. Finally, the Japanese Canadian community succeeded in this negotiation by placing this discussion, not within the issue of one of the minorities in Canada, but instead as an issue for “Canadian" society as a whole under the government's multiculturalism policy. 
In collaboration with other organizations that were advocating human rights, the Japanese Canadian leaders emphasized the violation of human rights by the Canadian government based on race and corresponding discriminatory treatments. This political movement also required ethnic resources and community engagement. The discussion of the commemoration of Japanese Canadian history intensified their ethnicity as Japanese Canadian, sometimes requiring the Nisei and the Sansei involved in the movement to represent their ethnicity in a way that emphasizes the "Japaneseness" as a minority group in their own identity (Kobayashi, 1992). In that movement, remarks Kobayashi (1992), in order to legitimate the representativeness as the "victim" of the political violence, they substituted the use of languages that described themselves - the change of languages from "Canadian" to "Japanese Canadian", from "evacuation" to "uprooting", and from "survivor" to "victim".

This work of the Redress activists was brought to a head with the government's agreement to a redress package including individual compensation of 21,000 dollars for each living survivor of the internment, community fund, official apology, and the foundation of a Canadian Race Relations Foundation. Although the ethnic awareness of Japanese Canadians surfaced largely for political reasons in the politics calling for the government's recognition of the historical injustice (Miki, 2004), the Japanese Canadian community has been ebbing its collective ethnic representation again since then (Kamo, 2010).

In addition to the political involvement in those days, the current socio-economic status and rates of inter-racial marriage among the Sansei is remarkable from a sociological perspective. Block and Galabuzi (2011) report the performance of the current visible minorities in the labor market of Canada. They remark that those who identify themselves as people of Japanese descent obtain more earnings and register lower unemployment rate than non-visible groups. In addition to this high performance in the labor market, Noro (2009) interpolates that multiracial population will outnumber that of uniracial in the Japanese 
Canadian community within the next decade, touching on the data demonstrating that the one-third of Japanese Canadians are multiracial. Regarding the inter-racial marriage as "the ultimate and most intimate form of the social acceptance", Makabe (2005) argues, there is "no barrier at all between them [the Sansei] and other groups in personal interactions".

It is undeniable that these changes and the ensuing success stories contributed to creating the image of Japanese Canadians as a highly assimilated group and their particular ethnic subjectivity as "Japanese Canadian" based on that. A lot of research on Sansei Japanese Canadians were produced in the late 1990s. It has been almost 20 or more years since this type of research was implemented. In the meantime, the geography in Toronto and the demography of the Japanese Canadian community has been changing in reflection of new immigrants, workers, and visitors from Japan. The influence of the particular experience of the Japanese Canadian Sansei on their ethnic identity formation and their negotiation for social inclusion in the city embracing multiculturalism will be more clarified in comparison with another emerging Japanese Canadian group, which has recently immigrated to Canada from Japan and has increased its population.

\section{$\underline{\text { New immigration from Japan and Ijusha Nisei's social background }}$}

A new flow of Japanese immigration to Canada was initiated by the amendment of the Immigration Act in 1967. This Act eliminated for the first time, the use of blatant racial criteria in the selection of immigrants. Compared with the first Japanese immigrants to arrive to Canada in the late 19th century, those who arrived from the 1960s on were called Ijusha, literally meaning "immigrant" in the Japanese language. Under the new "point system", the selection of immigrants favored financial and human capital in potential immigrants. The "point system" selects immigrants based on their potential to provide benefits to the Canadian economy through investment, entrepreneurship, and consumption, as well as the human capital that they can leverage for the development of the Canadian economy. Prospective 
immigrants under this system would accrue points based on education, occupational skills and experience, in addition to English and/or French proficiency. Reflecting the new immigration criteria, most of the Ijusha population are business persons, technicians, professionals, and entrepreneurs who have a relatively high educational background from metropolitan areas in Japan (Yamada, 2001). On this occasion, Canada did resume the incorporation of immigrants from Japan—notwithstanding it was a modest number at first.

Although the new immigration Act highlights the economic and human capital of Japanese immigrants, this does not mean that their immigration pattern corresponds to traditional pull-push factors in the labor market. The Ijusha's experiences of migration are diverse and must be comprehended from multi-dimensional perspectives. For instance, women make up about the two-thirds of this population (Kobayashi, 2002). In Kobayashi's analysis, Ijusha Issei women talk about the patriarchal social system in Japan and describe their immigration as a way to escape from this masculine social norm and start a "new life" in Canada. Minamikawa (2015) remarks that most Japanese people living in Canada for a long time describe Japanese society with a sense of stagnation, disappointment, and impasse in Japanese society. Their narrations of the immigration to and lives in Canada symbolically show the liberation of themselves form a "fetter" to Japan, which forced them to live in the extraordinary stern and normative society. However, they also notice that they cannot completely break this relationship to Japan. But instead they increase their awareness of Japanese identity by learning how differently people born in Canada live, talk, behave, and work as they increase interactions with them. Furthermore, the ideology of multiculturalism urged them to represent the ethnic identity in a positive way. In this ambivalent attitude towards Japanese ethnic identity, argues Minamikawa (2015), the positive representation of their life in Canada is partly a reflection of their own experience but mostly stems from a need and desire to justify and stabilize their "present" life. 
While negative reflections on Japanese culture may be observed in the Ijusha community (Kamo, 2010; Kobayashi, 2002; Minakimawa, 2011), the Ijusha population at the same time, express a strong need to maintain Japanese culture. This desire of cultural maintenance and the re-acknowledgement of cultural resources direct both Japanese Canadian communities towards forms of collaboration. For example, Yamada's (2001) ethnographic research on the Powell Festival in Vancouver reveals the identity negotiation of a variety of Japanese Canadians ranging from Japanese Canadian Nisei, Sansei, and Yonsei, to Ijusha Issei, and Nisei, through the participation in reconstituted traditional Japanese culture but in a specific "Japanese Canadian" mode.

Attempts to bridge the two Nikkei communities can also be observed in the city of Toronto, the second largest city in Canada for people who self identify as Japanese descent. In 2015, the Japanese Canadian Cultural Center (JCCC), the largest Japanese Canadian community organization in Toronto, incorporated a Ijusha community association, the New Japanese Canadian Association (NJCA), into the JCCC's organizational structure. The NJCA had been serving exclusively for new immigrants to Canada from Japan independently since 1976. The most prominent case along with this attempt is the Ijusha conference. This conference was organized in response to Ijusha community voices convincing that their migration history and memories were also a part of Japanese Canadian history, that should be recorded in the archives of the videotaped narratives of the Japanese Canadian Issei, Nisei, and Sansei.

Changes in the public image of Japan as a nation have also occurred. The increasing saliency of Japan in international relations since its rapid economic development in the 1960s accelerated the creation of a positive image of Japanese culture in North American society. Alongside the Japanese government's propaganda messages of "Cool Japan", this new and positive image of Japanese culture has also made the identification based on the Japanese 
cultural heritage palatable, legitimate, and acceptable to Japanese Canadians. Fomented by the boom of Japanese food and pop culture in Western society, this rise of the new population of Japanese Canadians also has changed the landscape of Toronto in the last few decades by creating more Japanese sushi restaurants and shops in Toronto neighbourhoods. At the same time, the JCCC started to be more involved in cultural events that represent Japanese culture. An increasingly visible Japanese landscape in the city provided occasions where both the early Japanese Canadian community and the Ijusah community encounter each other and share the place and experience in this "multicultural" city. From a critical scholarly perspective, this encounter prompts interesting questions about their identification as Japanese Canadian by surfacing another type of contemporary Japanese ethnic markers that are positively represented in consumerism society.

While these recent developments elicited by new Japanese immigrants, have been observed by the recent Nikkei community, they have not commanded a great deal of scholarly attention. Academic research related to Japanese Canadians does not for the most part problematize differences between the early Japanese Canadian community and the Ijusha community. The emergence of the Ijusha Nisei population in particular has been overlooked.

In this research study, I hope to address these gaps. I explore how the Japanese Canadian Sansei and the Ijusha Nisei interpret their experiences, with a focus on their encounters with Japanese culture and racialization based on the Asian body. The Japanese Canadian Sansei grew up, internalizing the widespread ideology of assimilation in their childhood and the counter-discourse against the violence of the state that the Redress movement brought in. By contrast, the Ijusha Nisei were born and raised up a decade later. While the positive image of Japanese culture started to be produced and spread, social exclusion based on the physical appearance was still at work. The different and complex social, cultural, and political backgrounds of Japanese Canadians compose diverse stories. I 
in detail describe those diverse stories and their interpretation of the stories through the oral history approach.

\section{Literature review}

\section{History and Collective Memory}

Academic discourse of history and memory has utilized the concept of collective memory to rediscover "forgotten" histories. Collective memory is presented as an alternate concept of the past, replacing the Western concept of history. The collective memories are concerned with the process by which a specific type of knowledge of the past is turned into resources of actors "now and here" in society. This awareness of the process of making history makes clear fundamental contradictions, not just differences between two concepts of the past, demonstrating the different modes of representation of and aspirations for the past (Wertsch \& Roediger, 2008). The differentiation of these contradicting concepts is predicated on the different recognition of temporality and subjectivity attached to the idea of past.

Nora explains that the dominant Western concept of history is "how our hopelessly forgetful modern societies, propelled by change, organize the past" $(1989$, p.8). In his account, although the Western concept of history reifies itself in its continuity to the present in a way that provides a rational linear explanation of the seamless time, its ontology is predicated on brutal detachment to the present in order to validate the "change". A break between the expectation of the future and the experience of the past has been "accelerated" by the notion of "progress". In this "historical acceleration", other possible interpretations of the past that do not fit the specific type of continuity and rupture are forgotten and suppressed by the notion of "progress". This detachment verifies history as "objective", "true", and "authentic" memory, which "belongs to everyone and to no one, whence its claim to universal authority" (Nora, 1989, p.9). 
Alternatively, from Halbwachs's perspective on collective memory, knowledge of what happened is multiple and what it means can be selectively determined. This selective and constitutive nature of memory - those represented values are more or less dependent on both past and present social conditions and the narrator's remembering "now and here" triggered in the literature, a discussion of the arbitrariness of memory and history. A new awareness of the arbitrariness of what stands as "objective" history has directed scholars of memory study to examine the procedural aspects of collective memory, as compared to just the represented values of memory. Such discussions have resulted in the unfolding of a discursive force of knowledge production in history.

Among many scholars of collective memory, Halbwachs is an oft-cited thinker who first articulated the process of the collective memory. Halbwachs distinguishes between history and collective memory based on the immediacy of the lived experiences emerging in the depiction of the past. He also differentiates the term of collective memory from a collage of personal memories by focusing on who remembers and in what social conditions this happened (Russell, 2006, p. 794). According to Wertsch \& Roediger, this focus on "collective remembering ... would give greater emphasis to the social and political contestation that is part of many accounts of the past" (p.319). In this sense, not just being a container of knowledge of the past in which the knowledge is static and established by being detached from the present, collective memory provides a social space for contestation over such knowledge. This space of contestation also casts doubt into the singularity of history because "memory can store, as regards individuals, idiosyncratically selected elements, which are nevertheless always social embedded" (Domingues, 1997). Noting that this contestation enables groups at present to contextualize and negotiate the meaning of the past, scholars of memory aptly call this political nature of memory, "politics of memory" (Keightley, 2010; Olick \& Robins, 1998; Wood, 2012). 
The politics of memory questions representation of an "objective" past in history. History cannot be detached from human interactions and negotiations at present because the belongings of history to no/everybody does not qualify equal accessibility to the process of making history. In explanation of Nora's conceptualization of Western history, Gedi and Elam remark that "there is some entity which is living, authentic memory and which has been completely distorted by historians and their critical methods" (1996, p.34). This distortion has dissected vernacular and official memory by using memory as a methodological evidence for the historicity of the facts based on archived knowledge (Dellios, 2015). Olick \& Robins (1998) describes this body of archived knowledge as the "dead memory" which lost "organic memory"; it entails subjective narrations in which the future is only imagined as an expectation based on the continuity from the past. The archivable static knowledge in dead memory, as extracted from organic memory is dispatched from past experience. Its attached values are concealed with universal authenticity and justified as the singular truth through its representation as the official public history. Such history creates a genealogy of the nation and insinuates whose contributions are regarded as legitimate in that genealogy. This is why, in this view, dead memory is regarded as a resource of the state to legitimate its nationbuilding project to construct the favorable image of the nation.

The notion of the dead furthermore implies the loss of dynamism that otherwise could reside in the negotiation of the past, especially the pasts of minority groups. Writing about the power of the state to create a favorable genealogical narrative, Bevernage criticizes the concept of "progress" in the national history because "the very idea of history as a unified process... only came into existence after the idea of progress opened up the future and people came to believe that they could 'make' history" (2010, p.115). The question is who has the power to "make" history and how this power is (re)distributed. Touching on this construction of history and its hegemonic power, defined as accessibility to the process of making history, 
Alonso (1988) writes that access to this power is limited to certain classes and groups, and through the construction of the official public history, these classes and groups accrue legitimacy to themselves that control the access to this process. That is how the concept of homogeneous nation and the assimilative ideology buttressed by the national history alienated the ethnic minorities from the mainstream society.

Drawing on these theoretical writings on memory, my own research suggests that the collective memory of Japanese Canadians has been leveraged against the national history that excluded their ancestors based on "Asian" phenotypical characteristics. By rediscovering "silenced" or "forgotten" stories, multi-disciplinary research on Japanese Canadians has revealed and criticized the hegemonic construction of Canadian history and the created subjectivity of Japanese Canadians (see for example, Fujiwara, 2012; Oikawa, 2012; Sugiman, 2004; Tupper, 2002; Wood, 2012). Oikawa (2012) in her book, Cartographies of Violence: Japanese Canadian Women, Memory, and the Subjects of the Internment elaborates on the "liberal" construction of the history of the Japanese Canadian internment by the state's interpretation and representation of the history congruent to the official Canadian multiculturalism policy. She expands the customs of rediscovering the forgotten subjects by spotting the missing stories of the white bourgeois supremacy, something that was an accomplice to this historical injustice.

While Oikawa (2012) focuses on the hegemonic construction of history, from a political perspective Miki (2004) and Omatsu (1992) detail negotiations between generations within the Japanese Canadian community around the meaning and content of the Redress movement. The Redress movement has drawn scholarly attention because this collective action entailed the remarkable introduction of cultural and ethnic resources, which in turn united the Japanese Canadian community again. Through this political process, a variety of 
personal memories were reconstituted around the symbolic meaning of the collective memory of Japanese Canadians.

On the other hand, this approach, generally speaking, is criticized because it presumes the collective action based on the static knowledge of ethnicity, in other words, "patterns of publicly available symbols objectified in society" (Olick, 1999, p. 336). As Conway notes, this socially assigned culture tends to "homogenise collective memory and thus to underestimate the extent to which collective memory can be a container for a diversity of colliding and fragmented meanings of the past" (2010, p. 444). The politics of memory needs to be developed in ways that collective memory can hold its advantage of containing diverse meanings of the past. Yet, can we conceptualize an ethnic identity that is predominantly influenced by the collective memory, without at the same time creating another essentialized notion of ethnicity that is objectified by the social tendency of homogenization? Further, if this is possible, how can it be achieved?

\section{$\underline{\text { Cultural Citizenship }}$}

In order to approach this question, I turn to the concept of cultural citizenship coined by Nick Stevenson (2003) among others. He remarks that "new power" of the current social and political system rests on "codes of information and ... images of representation around which societies organize their institutions, and people build their lives, and decide their behavior" (2003, p.331) His awareness of the "new power" in society directs him to the communicative capability of the civic society. Touching on the hiking popularity of the use of cosmopolitanism in the academic literature, he conceptualizes the cosmopolitanism, which is defined as "a way of viewing the world that among other things dispenses with national exclusivity, dichotomous forms of gendered and racial thinking, and rigid separations between culture and nature, and popular and high culture" (2003, p.332), as an ultimate goal that the civic society confers. Given that the idea of citizenship based on the cosmopolitanism 
confers full inclusion in the mainstream of society, Stevenson ascribes the ability of the cultural aspect of the citizenship to the inclusive communicative space in the cosmopolitanism society.

According to Stevenson, cultural citizenship emerges from the safety in prospective communications (Isin \& Turner, 2007). In a "communicative society", the civic rights secured by citizenship is more than the right to social welfare and political participation. In this communicative society, the cultural citizenship has to be capable of providing the inclusive public space where the groups marginalized based on their cultural, racial, gender, and religious affiliations can make their negotiations for social inclusion visible and "open the possibility of dialogic engagement" (Stevenson, 2003, p. 333). The bona fide cosmopolitanism desired by the cultural citizenship in Stevenson's account is usually impaired by the ongoing body politics. Tsuda (2014), ascribing the entitlement of social and cultural citizenship respectively to socio-economic upward mobility and cultural assimilation, argues that the concept of cultural citizenship has to provide a political space in which people who are marginalized based on phenotypical characteristics can claim racial citizenship. Tsuda's conceptualization of racial citizenship is based on a case study of Japanese American Sansei and Yonsei. The statistics and the history of Japanese Americans show that they attained the high rate of social-economic success and the cultural assimilation into AngloSaxon culture. However, most of them were marginalized from mainstream white American national identity and instead presumed as "culturally foreign" based on their phenotypical appearance. In this view, the racial and cultural citizenship should remain distinctive because "not all ethnic minorities are defined and excluded from the national community by both cultural and racial differences" (p. 409).

The political negotiation for social inclusion has been utilized by arguing that the collective memory of the ethnic community should be acknowledged as national public 
history. Löfström (2011) discusses the state's action of "symbolic inclusion" and the practically unavoidable "exclusionary favor of this symbolic action" under the current politics calling for the recognition of political injustice. In this politics of recognition, the claim-making orientation shifts towards "the status parity in society's institutionalized patterns of cultural values" (p. 95). This new trend is directed to those whose collective memory of historical injustice had been marginalized by the standardized criteria of national history, thus whose cultural identities had been not recognized as a legitimate membership of the nation. The state's recognition of the political wrongdoing in the past on behalf of all citizens symbolically represents the inclusion of the group that had been marginalized. However, this conceptualization of cultural citizenship requires a particular historical and cultural identification that throws people into a dyadic relation of the apology between a victim and a perpetrator. The third group that cannot align their cultural identity with either of them - victim or perpetrator - "are relegated to cultural-political limbo as either inherently incapable of entering the national 'community of memory' or as obligated to assimilate in it and to abandon their particularistic collective memories" (Löfström, 2012, p.105). This requirement of cultural citizenship is problematic when assimilation of their stories entail the internalization of particular "codes" that normalize their diverse memories.

The conceptualization of cultural citizenship based on the communicative society requires researchers to look into how the cultural and racial citizenship of Japanese Canadians are claimed in their narration of lived experiences and family's past. The following section argues from the perspective of the sociology of memory, why it is appropriate to look into the narration of personal memory in order to reach out to the active engagement in, and social dynamics of the negotiation for cultural and racial citizenship. 
$\underline{\text { Identity Politics and Collective Memory }}$

Many sociological analyses of memory have explained memory as a "social act" that is performed by individuals, "far more than spontaneous and personal" and reflects "personal and historical transformations, ideological shifts, changing relations of power, strategy and struggle" (Sugiman, 2004, p.364). This social act and the identity project in the individual narration is the main focus of this study. In this paper, I ask how we can understand memory as a social act in the complex interaction between individuals and collectivity. The interaction is an unfinished process of two dialectic forces. On the one hand, the interaction (re)produces the self-image through the internalization of social and community knowledge, sometimes even social ideologies. On the other hand, it is the interaction that transforms the collective knowledge and reconstitutes the collective identity in a way that is leveraged against or conforming to the framework of social inclusion and exclusion.

Collective memory has the potential to bring about critical discourse against hegemonic knowledge production through a uniform history, by reuniting the past and present with organic memories. The social spaces created by collective memory hold personal memories that are suppressed by the official history and constitute the anti-hegemonic power by presenting these personal memories in a collective form. As Sugiman (2004) acknowledges, "the personal act of remembering, woven into an analysis of culture and society, is after all, a political project" (p. 384). Once the collective memory is established, as in the case of the Japanese Canadian community during the Redress movement, the discursive knowledge of the collective memory is regarded as a cultural resource for people who are exploring their ethnic identity. Telling diverse stories, individuals explore certain commonalities among the stories, and thereby create meaning to their stories. In that process, can the collective memory continue to insure the capability of holding diverse experiences after the Redress movement somehow brought in a sense of closure - albeit the racialization 
is still at work - in the negotiation against social exclusion? If there is certain unfirming force of the collective memory, what "codes" are internalized for the use of the collective memory in their narration of the past.

This question depicts the dual roles assigned to individuals on a conceptual level. Writing about ethnic identity, Syed and Azmitia (2008) identify two aspects of ethnic identity. In their account, individuals internalize ethnic identity through the socialization process. This perspective on ethnic identity describes the notion of "self" as socially constructed. On the other hand, individuals also negotiate and reconstitute that identity. In this view, individuals' agency is conceptualized as a source of power that can transform subjectivities of the ethnic group. These two dialectic forces in ethnic identity formation may be observed in the mutually influencing and also contradictory forms of selves.

To reveal the dialectic relationship between individuals and ethnic communities in terms of creating and internalizing ethnic identity, Ashmore, Deaux, \& McLaughlin-Volpe, (2004) have investigated context-specific behaviors, attitudes, and beliefs. From their perspective, the narrative of lived experience is acknowledged as clues for researchers to look into "an individual-level collective identity element ... denot[ing] the internally represented story that the person has developed regarding self and the social category in question" (Ashmore et al., 2004, p. 96). In this dialectic relation, exploring and constructing their ethnic identity is not a linear process, but instead more complex project responding to various "social context, and opportunities for identity negotiation or, more generally, ... lived experiences" (Syed \& Azmitia, 2008, p.1014).

Collective identity is closely tied to collective memory on a conceptual level and this is because of the meaning of the past in identity formation. According to Hobsbawm (cited in Olick \& Robbins), "[t]o be a member of any human community is to situate oneself with 
regard to one's (its) past, if only by rejecting it" (1998, p.122). In this sense, identity is translated into an "ability" to quasi-subjectively experience events that happened to the ethnic group to which they feel belonging. With this ability, individuals go through "the mechanism through which we feel pride, pain, or shame with regard to events that happened to our groups before we joined them" (Olick \& Robbins, 1998, p.123). The referenced past in analog to their lived experience is not necessarily singular. In other words, the collective memory situates the occasion of personal remembering as a space for "a personal project that traverses national, ethnic and familial boundaries; ... these categories are co-dependent" (Dellios 2015, p.264). The possibility of an infinite number of catalogs of the past raises questions about how specific frameworks for the narration of people's lived experiences are selected out of many possible pasts.

Concepts of agency and actorhood in relation to the act of remembering among Japanese Canadians is also useful. Using an oral history approach, Sugiman (2004) addresses Nisei women's rejection of the stereotypical image of the submissive and silent female subject, an image that has been constructed in the master narrative of Japanese Canadian Nisei history in a way that "gives [them] agency to the subjects of history" (p.384). Theorizing the concept of memory, Sugiman also raises the question about the researcher's interpretation of an interview. Narrators, on one hand locate themselves in the history of Japanese Canadians and internalize the norm of the collective memory. But on the other hand, they demonstrate a process of creating their own meaning of the past by showing their agency in the selection of shared memories.

\section{Ethnic Identity and Japanese Canadians}

In looking at identity formation among Japanese Canadians, Miki poses questions about "[h]ow to speculate on the historical production of 'Japanese Canadian,' its contextspecific configurations, variations, and significances, without falling back on a fixed point of 
reference, some origin that it stands for?" (2005, p.95). Miki also notes that fragmentation of the subjectivity of Japanese Canadians has become a "double-edged site": discursive space where they are forced to be an "other" by the ongoing racializing discourses and institutions and/or where the critiques of this exclusionary force configure a collective form of negotiation (Miki, 2000, p.53). Appreciating the latter critical location of the "double edge", he argues that the Japanese Canadian becomes "a localized subject" that is engaged in the "re-inscription" of its meaning by reproducing and refusing the cultural production of their subjectivities in history. At the same time, he notes that "it is in this passing [of time epitomized by the Redress] that an identity formation so closely bound to the trauma of uprooting and dispossession was itself dispersed in what came to be a 'post-redress' time" (2005, p.109). The ethnic identity formation that is bound to the trauma prompted the Japanese Canadian Sansei to develop a connection to the cultural and memorial heritage in order to negotiate the legitimacy of their ethnic identity in relation to Canadian society.

Much scholarly literature speaks to Japanese Canadians' attempts to negotiate ethnic identity in positioning their life stories within a collective ethnic community experience (see for example, Makabe, 1998; Sarkowsky, 2008; Sugiman, 2004, 2006, 2009). This body of research - although it criticizes socially created racial or/and gendered stereotypes - does not fully touch on the implications of the Redress movement for the current negotiation for social inclusion attempted by Japanese Canadians. Identity formation in individual life accounts as "Japanese Canadian" is extended from the perspective that the representation of their stories is a negotiation for their national belonging. Narration of the past as a negotiation for national belonging translates the collective memory into one of the resources to negotiate their cultural citizenship in Canada. It is also important to discuss when and how this resource is used by narrators in relation to the codes that the collective memory insinuates. 
The identity of Japanese Canadians in relation to collective memory has been showcased in a range of research studies. Miki (2005) uses the metaphor of "alchemy" to describe a transformed Japanese Canadian identity during the Redress movement. $\mathrm{He}$ demonstrates the paradoxical nature of Japanese Canadians in the political and social movement. In that movement, the "Japaneseness" that used to be the "antithesis to transcending the gate of assimilation, was accruing cultural value as an ethnicity that should be recognized and preserved" (p.97). On the other hand, says Miki, the discursive "frameworks that had once excluded [Japanese Canadians] as Japanese or 'Asiatic' and deemed "undesirable"' (p.98) have to be utilized for the enactment of righting the political wrong. Despite this ironical situation, he optimistically expects the potential of this Japanese Canadian identity shift of the "post-redress" period as "the nexus of a subject-oriented discourse of identity-making, resistance, and opposition" (p.106).

This theoretically self-regulated process of identity-making hits the wall when it comes to dominant exclusionary public discourses that impose ethnic or racial categorization based on the physical appearance. In other words, the cultural and corporeal marker of their difference - socially perceived visibleness that the official categorization of visible minority indicates - reifies them as marginal "others". Criticizing a fetishized otherness in a society that espouses multiculturalism, Ahmed argues that "the strange body can only become a material 'thing' that touches the body-at-home, or a figure that can be faced in the street, through a radical forgetting of the histories of labour and production that allow such a body to appear in the present" (Ahmed cited by Miki 2005, p.100). In this social imagination of fetishized ethnicity, ethnic identity is regarded as a "thing" consumed by the uncritical curiosity of the mainstream Canadians who have forgotten the history.

Tsuda's (2014) research on the racial alienation of later-generation (Sansei and Yonsei) Japanese Americans provides an incisive lens into this issue. His research 
demonstrates that "it is apparent that most Japanese Americans cannot escape their racial essentialization as foreigners despite their cultural assimilation and socioeconomic integration into mainstream American society" (p. 413).

As opposed to the negative essentialization of foreignness in American society, Makabe (1998), through in-depth interviews with sixty-four Japanese Canadian Sansei, claims that to the Sansei in the city of Toronto, identification as Japanese Canadians is symbolic. It is described as a sense of "feeling ethnic as opposed to being so" (p.96). Makabe's research is intended to describe the "subject-oriented discourse of identity making" of the Japanese Canadian Sansei based on their structural and cultural assimilation. But the limitation of this perspective lies in its one-way reduction in the interaction between individual Japanese Canadians and society. She ascribes this agency over their identitymaking process to the successfully assimilated figure of Japanese Canadians, emphasizing and, in the worst case, stereotyping the "100 percent Canadianized" Sansei, who lacks the memory and cultural transfer from the Nisei population and the political engagement in the ethnic community. From Miki's perspective, talking about Japanese Canadians in this unilateral process - the social pressure of assimilation - neglects the fact that "processes of racialization are never simply one-way and imposed, but are dynamic and folded into specific limits" (2005, p.105). This research project critiques these limits coming from the " 100 percent Canadianized" ethnic identity by showing how the Japanese Canadian Sansei feel obliged to these specific stories that describe themselves as assimilated figures.

As the research above demonstrates, reflections on the identity of Japanese Canadians have been advanced along with the "politics of memory". The conceptual foundation in which the identity politics of Japanese Canadians is discussed is limited in its potential however because, as Miki indicates, discussion of the ethnic identity formation of Japanese Canadians does not fully comprehend the effects of the historical injustice and the 
Redress movement on the current negotiation for social inclusion. To address this gap in the literature and to examine new and continually evolving Japanese Canadian identities, I draw on the cultural theorist's understanding of diasporic identity.

\section{Diasporic Identity in the Nikkei Community}

Diaspora study focuses mainly on transnational practices between ethnic communities and their homelands (Tsuda, 2012). The ontological foundation of the diaspora identity rests on "a biologically essentialized assumption that those of shared racial descent and blood ties will retain their common cultural heritage over time" (Tsuda, 2012, p. 98). While diasporic identity owes its existence to an essentialized notion which intrinsically reifies the difference with rigid boundaries insinuating that they have a "body" from outside of the country, cultural theorists have attempted to define the diaspora identity by contextualizing its formation of identity in the contestation between belonging and otherness.

With the subjectivities of Japanese Canadians in the double-edged site shown in the aforementioned discussion, their identity becomes fluid and multiple. Diaspora study has attempted to theorize fluid and multiple identities as sites of transcendence of old concepts of ethnicity that is preoccupied with the fixation and stabilization through the rigid classification (Hall, 1996). Hall and his successors name the nature of this site "hybridity" (Anthias, 2001). This awareness of hybridity directed the scholarly attention to - rather than "objective social reality" - "a type of identity, subject formation, and discursive awareness, often based on collective memories, histories, myths, narratives, and cultures” (Tsuda, 2012). Diaspora identity does not, or more precisely is not able to, evade the influence of the "old ethnicity" which is normalized by discourses of the "Other" that places them at the margins. Racialization is at work over generations because people of Japanese descent are assumed to "be culturally different" by virtue of their race as represented through bodily appearance and cultural signifiers; the social perception of difference does not allow them to be non-ethnic, 
or included in the mainstream group which is associated with Anglo-Saxon white culture (Tsuda, 2014).

The particularity in the Japanese diaspora in North America is the intense degree of cultural assimilation. Tsuda (2012) mentions that the Japanese diaspora community in the United States lacks two major characteristics: "centripetal attachments to the ethnic homeland" and "lateral pan-ethnic affiliations with their co-ethnics abroad". Although his research on the identity of Nikkei people in the United States describes in detail the uniqueness of their ethnic consciousness without these diasporic natures, it does not go so far as to say that the lack of lateral pan-ethnic affiliations with co-ethnics within the country between the early Japanese Canadian community and the Ijusha community. Tsuda also does not explain what experiences constructed this uniqueness while they maintain ethnic consciousness.

The maintenance of a cultural heritage and the desire for it are observed in the Japanese Canadian Sansei and Yonsei youth and/or multi-racial backgrounds. As opposed to the highly assimilated image of Japanese Canadians, Sansei and Yonsei Nikkei youth attempt to recover their ethnic heritage through language school and cultural events (Noro, 2009; Tsuda, 2015). Tsuda (2015) in his ethnographic research on Japanese Americans in San Diego argues that this reorientation to Japanese culture is a response to the group's continued racialization as "Japanese" and a reflection on the overassimilation to American society. Compared to Tsuda's detailed analysis of Nikkei identity in the United States, the ethnic tie based on Nikkei identity has been uncritically presumed in research on Japanese Canadian community (Yamada, 2001; Izumi, 2001) and therefore the constructed diaspora space around the Nikkei identity in Canada has been ignored. 


\section{Methodology}

\section{Oral History in Narrative Research}

In order to understand the complex dynamics and multiple dimensions of individual identity formation, this research uses the narrative approach. Narrative research is defined as an umbrella category of research methodology that starts with "the experiences as expressed in lived and told stories of individuals" (p.70) such as biographical study, Autobiography, life history study, and oral history (Creswell, 2012). Although narrative work was likely to be regarded as a consequence of a series of events and experiences in social science. Recent research has developed narrative research by recognizing narratives as not only methods to explore the experiences and themes but also social phenomena (Atkinson \& Delamont, 2006; Clandinin, 2006; Creswell, 2012; Peterson \& Langellier, 1997).

I adopted the oral history approach in particular. The oral history approach enables us to explore the identity articulated in both their narratives themselves and ways that they represent their narratives. From the feminist perspective, Sangster remarks that "asking why and how women explain, rationalize and make sense of their past offers insight into the social and material framework within which they operated, the perceived choices and cultural patterns they face, and the complex relationship between individual consciousness and culture" (1994, p.6). The awareness of how to make sense of the history elaborates on the narrators' agency and group interest over the construction of the history as a form of the collective stories.

Based on this understanding of narratives, oral history has been used to contest the dominant discourse and practice (Creswell, 2012; Esser, 2012; Fraser, 2004). The oral history approach has contributed to enhancing our perspectives on history and memory in a manner that acknowledges the diverse identity of people who have been overlooked in a monolithic history. This does not mean though that oral history provides "more history, compensating 
where we have no other sources, or better history, a purer version of the past coming, unadulterated, from the very people who experienced it" (Sangster, 1994, p.7). What the oral history approach offers is not a quantitative increase in some kind of measurable sense of the past. Rather, it offers a critical awareness of the framework that constitutes history as more than the neutral collection of stories. The methodological turn to who tells and how to tell the story makes narratives more multidimensional in terms of time, space, private and public milieu. Multidimensional spaces in which both a narrator and researcher are engaged, can highlight the often complicated relationship between the researcher and the researched (Clandinin, 2006). In Clandinin's account, narrative inquirers cannot disconnect themselves from this relational dimension to research participants. Ideally, they are engaged in the reconstruction of stored experiences. In this sense, oral history narratives are best understood as the collaborative work of a researcher and research participants (Creswell, 2012).

The collaborative feature of oral history underlines two important tasks. The first one is to be aware of the unequal power between the researcher and the researched. A lack of awareness of the complex contexts of narratives and imbalanced interactions can reproduce, not deconstruct, hegemony (Esser, 2012). Closely related to need to be aware of the power imbalance in an interview, researchers have to be self-reflective in every single process of the research. This reflexivity is implemented in my research by clarifying my motivation for research and revealing personal and emotional connections to the experiences of participants (Sugiman, 2004). Sugiman (2004) caveats, borrowing Michael Frisch's terminology, that oral history researcher has to explore the way to "share authority" over their narrative.

An important objective of oral history is defined not to generalize experiences but rather to uncover a variety of stories which should be told as well as the factors and contexts which storytellers interpret certain experiences in their lives. In this research project, lived and told experiences of participants are interpreted as the space where the individual identity 
politics take place in a way that reconciles and negotiates their national belonging to Canada and self-consciousness of diaspora or ethnic identity. Their storytelling is regarded as narratives in which negotiation for the articulation of their identities reconstitutes their subjectivities of Japanese Canadian.

\section{$\underline{\text { Research Sample }}$}

In this research study, I used purposive sampling (see Creswell, 2012; Gentles, Charles, Ploeg, \& McKibbon, 2015; Patton, 2002). Patton argues that "the logic and power of purposeful sampling lies in selecting information-rich cases for study in depth. Informationrich cases are those from which one can learn a great deal about issues of central importance to the purpose of the inquiry, thus the term purposeful sampling" $(2002,273)$. Purposive sampling is used in oral history research in order to assist researchers to reach out to these information-rich stories, not information-rich people per se. Information-rich stories do not indicate that some people are information-poor and their stories are not worthy of being told. But rather every single person has stories worthy of being told. Given this premise, purposive sampling helps researchers to spotlight on people who have specific experiences, which in most cases have been excluded from the body of academic knowledge.

Additionally, in order to generate information-rich stories, I used the snowball sampling method. I first reached out to my personal contacts from the Japanese Canadian community, individuals whom I have met through volunteer work, participation in cultural or memorial events, school work, and research conferences. I have categorized one group as Japanese Canadian Sansei (third-generation). This includes people whose grandparent(s) immigrated to Canada before World War II and directly experienced the Internment. The other group is the Ijusha who are comprised of those whose family (parents, grandparents) immigrated to Canada between 1960 and 2000. For the purposes of this study, the Ijusha population is limited to the Ijusha Nisei, those whose family immigrated to Canada between 
1960 and 2000. Not included are the Ijusha population who stays in Canada with study permit or work permit. Ethnic awareness as Japanese Canadian among the Ijusha Nisei will be developed in the socialization process throughout education system, employment, and long exposure to communities in Canada. From reasons cited above, this research is also limited to those ages between 22 and 65 older.

Generation, age, race and ethnicity (multi-race/ethnicity), and gender are also important factors in my research. It is, in particular, noteworthy that the category of Japanese Canadian can be an operationalized category as well as an identity which is continuously reconstituted and actually researched in this project. In this sense, I will leave the interpretation of Japanese Canadian open to potential participants in order to look into this dynamic of identification. This consideration is also reflected in the generational profile of two research participants (see Table 1).

\section{General Interview data}

For this study, I recruited a total of eight participants (four Sansei and four Ijusha Nisei) See Table 1. Of the four Sansei, three are women and one is a man. Among the Injusha Nisei, there were three men and one woman. All of the Sansei participants are in their early $40 \mathrm{~s}$ to late $50 \mathrm{~s}$. Three Ijusha Nisei participants are in their $30 \mathrm{~s}$ and the youngest is 26 -year of age. Pseudonyms were assigned to each of participants. Participants with Japanese name were assigned Japanese pseudonyms. The occupations of the Sansei include: financial representative, technical sales specialist, director of information strategy, and accountant. Ijusha Nisei participants are employed as a manufacture salesperson, high school music teacher, firefighter, and salesperson.

Considering my objective of revealing multifaceted stories of Japanese Canadians, I also decided to recruit two individuals. One is a " 3.5 generation Japanese Canadian". This is 
a person who has a Nisei father and a Sansei mother. The other is an Ijusha Nisei/Japanese Canadian Yonsei who was born between an Ijusha Issei father and a Sansei mother. Stories from the more diverse population within the Japanese Canadian community enrich the information about the ambivalent and seemingly trivial nature of the individual identity politics in narrating their stories.

\begin{tabular}{|l|l|l|l|l|l|l|}
\hline Pseudonym & $\begin{array}{l}\text { Year } \\
\text { of } \\
\text { birth }\end{array}$ & Gender & Occupation & Father & Mother & Marital Status \\
\hline Sophia & 1958 & Female & $\begin{array}{l}\text { Financial } \\
\text { representative }\end{array}$ & Nisei & Nisei & Married \\
\hline Jessica & 1961 & Female & $\begin{array}{l}\text { Technical sales } \\
\text { specialists }\end{array}$ & Nisei & Nisei & Widow \\
\hline Natalee & 1956 & Female & $\begin{array}{l}\text { Director of information } \\
\text { strategy }\end{array}$ & Nisei & Nisei & Married \\
\hline Patrick & 1972 & Male & Accountant & Nisei & Sansei & Married \\
\hline Ken & 1989 & Male & Salesperson/Consultant & $\begin{array}{l}\text { Ijusha } \\
\text { Issei }\end{array}$ & $\begin{array}{l}\text { Ijusha } \\
\text { Issei }\end{array}$ & Single \\
\hline Charles & 1980 & Male & Music teacher & $\begin{array}{l}\text { Ijusha } \\
\text { Issei }\end{array}$ & $\begin{array}{l}\text { Sansei } \\
\text { Married }\end{array}$ \\
\hline Kenji & 1977 & Male & Firefighter & $\begin{array}{l}\text { Ijusha } \\
\text { Issei }\end{array}$ & $\begin{array}{l}\text { Ijusha } \\
\text { Issei }\end{array}$ & Married \\
\hline Nozomi & 1983 & Female & Salesperson & $\begin{array}{l}\text { Ijusha } \\
\text { Issei }\end{array}$ & $\begin{array}{l}\text { Ijusha } \\
\text { Issei }\end{array}$ & $\begin{array}{l}\text { Common-law } \\
\text { Married }\end{array}$ \\
\hline
\end{tabular}

Table 1: Profile of Interview Participants

Interviews in oral history

Interviews were conducted in a semi-structured way (see the interview guide in the appendix). I kept myself open to emerging issues in the interviews and responded to them by asking follow-up questions. If participants felt more comfortable being interviewed in Japanese than in English, I would conduct the interview in Japanese. One participant of the Ijusha Nisei population asked that the interview be done in Japanese. These interviews were recorded and transcribed upon the interviewees' consent.

In the oral history approach, an understanding of the contextuality of interviews is important. The researcher is regarded as a co-constructor of the interview narrative and an 
interviewee is producing situated accounts of their narrative in this collaboration. As well, many oral historians openly acknowledge the power imbalance between researchers and participants. The breaking down of the authority of researcher was attempted - although not fully achieved - by telling them that my intention to have interviews as conversations and encourage them to ask me if they have any questions during the interviews.

While the oral history approach is ideally collaborative, the researcher nevertheless plays an important role in interpreting and analyzing collected stories. Taking into account feminist perspectives on storytelling as the act of unfolding people's perspective on their own experience and the collaborative promise of the oral history, Creswell (2012) calls the process of analyzing oral history interviews "restorying". Restorying is the process of reorganizing stories into a framework that makes senses (Creswell, 2012, p.74).

One of the key elements in the process of restroying is chronology. A chronology is composed by "ideas" of past, present, and future. In order to reveal how and why narrators chose to relate a certain memory, researcher seeks for the "turning point" in their oral history that shaped and influenced narrators' perspective (Creswell, 2012). Sugiman (2004) notes that the paradoxical nature inherited in the ideological assertion of the linear and objective historical time might ignore the narrators' subjective sense of the passing of time. She caveats that if there is ambivalence residing in time, this is not fixed by the researcher. Rather, it should be analyzed considering what shapes this ambivalence in their narration. In this sense, a chronology is not the container of their story but assist researchers to reach to their subjective time and subjective experiences, demonstrating the ideas attached to their past, present, and future stories.

The researcher's analysis sometimes "restories" the narrator's stories in chronological order based on themes emerging from memories. It also has to deconstruct the stories in light 
of the social, cultural, and historical contexts of the storytelling (Creswell, 2012; Keddell, 2009). Caruthers (2005) in a study of the desegregation of the American education system uses "storytelling as a way to talk about the "undiscussable" related to race/ethnicity, class, and gender" (p. 26). Storytelling encourages participants to tell their subjective experiences shaped by the norm of race/ethnicity, class, and gender. The undiscussable emerges in the process of deconstructing in which the researcher examines cultural and ideological context. This process reveals what turns their thoughts of race/ethnicity, class, and gender, responses to a certain event that presented as the undiscussable issue, and interpretation of the past with the undiscussable issue, into "natural", "taken for granted", and "normative". If participants show the normalization of their stories, researchers have to be aware that the context makes up the norm.

\section{Analysis}

Japanese Canadian Sansei: To be aware of being Japanese Canadian

One of the themes that came up during my interviews is the perception of visibility as a Canadian of Japanese descent. All of the participants mention that at least before entering a public school, they did not have any sense of "difference" and specific notion of their cultural background. They described that they grew up thinking that they were very "Canadian". An awareness of being viewed as "Japanese" was first recognized when they entered a public school and surrounded by "Caucasian" classmates.

I think we grew up thinking that we were very, very Canadian, Canadian first, Japanese second. We grew up in a suburb. There were only two or three families in the area that were Japanese... My mom said, when my younger brother, he is two years younger [than me], came home from school, I don't know if he was grade one or not. He was so excited because there was a Japanese kid in his class. She [her mother] looked at him [and said], what do you think you are? [Laughter] (Natalee, Japanese Canadian Sansei, emphasis was made by Natalee)

I guess I never identified myself really different until ... uh... probably early grade school. I guess, at the beginning, it just never occurred to me that I was different than other kids. I know when we were young, [we] do all the crayons like crayon boxes 
[with] all those different colors. I thought it was kind of funny because they [Caucasian kids] had flash color, like a crayon. But that [his skin] was not quite the same ... [Laughter] ... as a color. (Patrick, 3.5 generation Japanese Canadian)

All of the Sansei participants in my study lived their childhood years in predominantly white neighborhoods. They had only a few Japanese Canadian families in the same neighborhood, and the interaction with these families was minimal unless they were immediate relatives. In regard to their participation in Japanese cultural events, New Years' day was the only one that they celebrated. On this day, families assembled at one family's house that was assigned to each family year by year or grandparents' house every year. They would bring homemade dishes, most of which were Japanese Canadian food such as chow mein, mochi (rice cake), and so on.

In these neighborhoods, they did not learn cultural and memorial heritage from their parents and grandparents. The Japanese language is one of them. Since they did not learn any language other than English as they were growing up (their parents spoke to them only in English), they could not build intimate relationships with their grandparents. After all, their grandparents' first language was Japanese and they could not speak English very well. Sophia described her relationship to her parents and grandparents in her childhood with her sense of the loss of Japanese heritage.

They [her parents] never talked about it [their experience of the internment and Japanese culture], they only spoke Japanese to their parents [her grandparents]. We never learned about our heritage... We related not much about being Japanese. We did not ask either. We did not know about being Japanese... We didn't really interact with them [grandparents]. Because we did not understand them, and I don't think they understood us. (Sophia, Japanese Canadian Sansei)

Remembering her childhood and the scarce chances she had to learn about her Japanese heritage, Sophia said, "I figured that they just wanted us to be a Canadian and Canadianized". All the participants note the influence of the "fitting in" pressure on their life. They remarked that their parents were urged by the traumatic experience of internment to fit in to Canadian 
society and also not to pass down the cultural and historical knowledge of Japanese Canadians. These environments of their upbringing that limit and almost shut out the exposure to their family past and Japanese cultural heritage are the significant elements that register Japanese Canadian Sansei’s lack of ethnic identity in childhood.

As the passage above indicates, an awareness of bodily "difference" was first provoked in school settings by physical markers. However, this was not described or perceived by all. In fact, two participants (Sophia and Jessica) mentioned that they did not feel any sense of difference during their school days. In contrast, remembering his childhood, Patrick describes the awareness of his physical difference in an analog to the awareness of gender.

There is an underlying understanding in a lot of people that what they picture when they are looking for a somebody from an opposite sex affects how they do things, and so there's a certain thing... I guess at that point, more of my friends became Oriental, not necessarily on purpose, there were several my friends who were oriental and, but those tended to be people who didn't really care about what your background is. (Patrick)

Patrick also acknowledged in the following conversation that he, intentionally or not, fell into the group racially categorized as "Oriental" or "Asian" and attempted to naturalize this. This perception of early life as an "Oriental" insinuates how he internalized the essentializing subjectivity of the Japanese Canadian as a racialized "other". The racialized term "Oriental" has been used to alienate and objectify people of broadly Asian descent as the "exotic" and the "foreign" by the white mainstream culture. The usage of this terminology and the acknowledgement of his belonging to that group projects his own perception of foreignness assigned to his bodily appearance in those days.

Patrick buttressed his naturalizing attitude towards the internalization of the essentialized subjectivity in comparison to people who are marginalized people by their sexual orientation. By talking about the social issue of lesbian, gay, bisexual, transgender, and 
genderqueer (LGBTG) later in the interview, he indicates that the embedded social order forced people to follow certain social norms that shows what is taken for granted and natural. This comparison demonstrates that there was a sense of racial hierarchy in the educational institution. The hierarchy based on race not only creates a border between groups but imprints a sense of marginality, urging people assigned as the "Oriental" to behave as if they are not "Oriental". They tried to mask their ethnic identity, and this rejection of their unavoidable essentialized subjectivity led to a self-hatred and/or self-rejection behaviours.

Reactions to this racialization is a compound of acceptance and negation. On the one hand, the essentialized subjectivity as an "other" that is incongruent to the "assimilated" self as a "Canadian" is perceived as the norm of the society of "Canadians". In this sense, internalizing the essentialized subjectivity that is epitomized as "other" paradoxically constructed a strategy of the negotiation for social inclusion. On the other hand, due to the dissonance that they contain in that identity - the dissonance that while they internalize the "Canadian norm", this very Canadian norm excludes themselves from the national belonging based on the phenotypical visibility - they were urged to reject this essentialized notion as "others".

In this ambivalent reaction, self-identification as Canadian is more connected to the loss of Japanese culture and largely not being Japanese. Then social assignment of others based on the corporeal Japaneseness pushes them into the cognition of themselves not belonging to both sides of society. The precariousness of this fragile sense of belonging emerged through the encounter of the similar racial topology. For example, Natalee shared with me a story about her fear of being prejudiced when her school music band went to the United States for an exchange program. Aware of ongoing racial segregation in the United States that was demonstrated by a question if the band had a member who was black, she 
"wondered what they were gonna do with me. Because I am Asian. I didn't know whether or not I was going to be discriminated against. Because you were in-between. That's the thing."

The experience of such exclusion based on physical difference is also observed in a small talk that is still repeated to this day. "Where are you from?" and "how long have you been here?" are typical questions that force them to be aware of the subjectivity of people of Asian descent. Natalee and Patrick explained,

... I remember I am getting that kind of question ah... growing up and you meet new people and [they ask] how long have you been here? Well, I have been here for all my life. If you are gonna play that kind of game, my family has been here for hundred years, how long has your family been here? Oh, twenty. They just assume that if you are a visible minority even you are fresh off the boat. (Natalee)

You have people who [say] go back to where you came from, stuff like that. Then I am like, okay, I think my family has been probably longer here than your family has been here. I would tell you to have to go back to where you came from, too, because no one is likely to be an indigenous person. So, I'm sorry. [Laughter] (Patrick)

Despite the long history of Japanese Canadians, they are still excluded from the racial membership of Canada by being assigned otherness based on visibility inscribed in the body. This social assignment of "who they are" informs the Japanese Canadian Sansei the mistaken assumption that they are immigrants, some even "fresh off the boat". This unspoken assumption about what phenotype can be entitled to be Canadian is further revealed by questions that follow when their answers are not unexpected such as "I am Canadian" or "I have been here since I was born". Then, they go far beyond to ask mother' and grandmother' background to satisfy their expectation. As the cases above show, they utilize the history of their family, not their place of birth per se, as a strategy to legitimate their sense of belonging to Canada. These questions impair the jus soli basis of Canadian citizenship. As Tsuda (2014) notes in the discussion of the racial citizenship in the United States through the case study of Japanese American Sansei and Yonsei, this is the negotiation for equal access to social rights that is repeated in daily experience. Especially, in the form of oral history, this persuasion 
utilizes the collective memory of Japanese Canadians as a resource for this negotiation. Their sense of belonging to the nation is recovered by the collective memory that they can prove the political and historical legitimacy of the belonging.

The sense of in-between status because of racial exclusion and the loss of cultural connection to Japanese heritage are further developed by experiences in Japan, or meetings with Japanese people in Canada. Language is the most obvious signifier that they are not Japanese. Recalling his college days, Patrick described his experience of the in-between status between Japanese and Canadian. This experience is shared by his "Caucasian" friend, who was raised in Japan because of his father's work and can therefore speak perfect Japanese. According to Patrick,

Two Japanese girls were sitting right across the table and looking at us very strangely because I look Japanese but I speak perfect English and he looks Caucasian but he spoke perfect Japanese. They sat there for 15 minutes looking at us like we were a badly dubbed movie, kinda different (Patrick).

This experience is interpreted as the ongoing phenotypical domination in terms of the classification of people but also as the desire for that classification based on the predetermined category.

Natalee also narrated four months stay in Japan in her 20s as another occasion where she "stood out" in Japan as she lives in Canada but in a different way, and also learned how different she was from Japanese people there. She stated,

But, I know that I stood out just like here [in Canada], I can pick up someone who is Japanese [by] the way they dress, the way they walk. Conformation [comes] when I hear the talk. It's the way they move. And also for girls just the way they move. You can tell, so over there [in Japan] they can tell [I am not Japanese]. (Natalee)

While Natalee notes that the her four months in Japan allowed her to espouse her own skin comfortably by connecting her body to the long history of Japan she learned in the travel, the Japanese knowledge of gender on how women should behave in public delineated her 
internalized Canadian gender norm and strengthens her sense of being Canadian. Through this experience, she recognizes her cultural connection to Japan as additional and minimal based on the culturally assimilated behaviour representing "Canadian" self.

\section{$\underline{\text { Redress Movement as "space for dialogue" }}$}

In terms of the recognition of their own history as at the core of their ethnic identity, the Japanese Canadian redress movement had a profound impact. Although the four participants in this interview were not directly involved in the redress negotiations, the change in the Japanese community accompanying with this social movement forms a turning point in their lives. All of the participants noted that the rupture between the Nisei and the Sansei was deeply grounded because there was no occasion that the Sansei could learn the past of the Issei and Nisei and because most of them were not willing to talk about their own experience in fear of the resurgence of painful memories and victimization. As Kobayashi (1992) says about the redress movement, this political contestation of the historical injustice necessitated the transformation of the Japanese Canadian community from the "assimilated Canadians" into the culturally distinctive "minority" within the multicultural society. The initiative for this transformation in Toronto was mainly taken by the JCCC in cooperation with other Nikkei organizations.

One of the influential initiatives they took was "Metro Toronto International Festival Caravan". In this festival, each ethnic community in Toronto built their own pavilions where they presented their culture in a form of art, dance, music, food, and so on. Holding the Tokyo pavilion in this festival, the JCCC involved a large number of volunteers in this cultural representation. Sansei participants unanimously pointed out this volunteer experience as a turning point that resulted in the expansion of their network within the Japanese Canadian community. In the festival, many Japanese Canadian volunteers including Issei, Nisei, and Sansei performed martial arts, Odori (Japanese dance), Taiko (Japanese Drum), 
showcased Ikebana (Flower arrangement), and served Japanese food such as Teriyaki chicken, Sushi, and so on. This community-based event involved all multiple generations in embracing multiculturalism in Canada. In doing so, it also promoted the dignified assertion of the "transplanted foreign culture". The cultural festival helped publicly represent Japanese cultural traditions, which were formerly hidden from the public and held only within the community, as a positive distinctiveness in multicultural Canada.

On this note, Sophia saw her greater involvement in the JCCC as derived from the comfort with which she relates to the tradition, in a way that verifies a new recognition of Japanese heritage. She explained,

It was just interesting, because when we grew up we did not know many other Japanese people, Japanese background, so it was just a kinda, like, you felt more comfortable, more comfortable because you can relate to the tradition you do. (Sophia)

On the other hand, the deep divide etched between generations remained as a scar on the community. Natalee told that the geographically inconvenient location of the JCCC, which was and still is the main gathering space in the Greater Toronto Area, limits the regular involvement of most Japanese Canadians. Most of the Issei were already retired and could not drive far. In addition, the Sansei was busy schooling and working in their 20s and 30s and they felt that the JCCC did not properly respond to their need to be connected with other Sansei.

In response to these needs, a Sansei group planned to create a new space by renting a room in a more accessible location. This plan crystallized into the establishment of an annex of the Japanese Canadian Cultural Centre. Although the rent for space was partially funded by the JCCC and they named the facility annex of the JCCC, the annex provided a unique experience independently. It served as a gathering space for the retired Issei generation in the morning and afternoon and provided social events at night for the Sansei in Toronto. These 
social gatherings regularly exposed the Sansei to other Sansei who have the same cultural background.

The needs expressed by the Sansei also mobilized the Sansei nationwide to hold a national conference. This conference was held in 1977 as a part of Japanese Canadian Centennial celebrations, bringing in many social Nikkei activists and a large number of Sansei from across Canada. Natalee mentioned the Sansei's unreconciled sense of stagnation in terms of self-identification dispatched from the parents' generation.

The Sansei were really grappling who they were and how they were different from their parents, what their identity was as a generation, they held a conference, I don't know what year it was, a national conference, a couple of days long, on the Sansei... to help give a space to dialogue what it meant, it was called where do we go from here, I think... The Redress, I think it had already happened. There was a sense of closure for the Nisei. But the Sansei were feeling the ethnic loss (Natalee)

In comparison to the sense of closure that the Redress movement, which actually took place in 1988, ten years after this Sansei conference, brought in the Nisei population, she explained the sense of cultural and memory loss still remained in the Sansei population. Setting up the workshops in a form of dialogue, this conference provided a space to share the experience of how different they were from other generations and how they recognized the loss in relation to the Japanese heritage as their roots. For most of the Sansei, who grew up in the neighborhood where the exposure to other Sansei was limited, this official space for the dialogue was meaningful in "re-identifying" themselves. This re-identification was not directed to the singular understanding of themselves. But rather, this created space gave them leeway to acknowledge the in-between as the very basis for who they are, not as a precarious status longing for the singular interpretation. The complexity and uncertainty are internalized in this in-between self-recognition, based on which they performed and enacted their own understanding of ethnicity in their narration of the past. 


\section{Making sense of the past in the present}

The disconnect between who they think they are and whom others think they are poses a critical question about their belonging to the nation. Retrospectively, they tried to make sense of this dissociation in the process of narrating their past from the perspective of the present. In this sense, the "Canadian" way of life is not a specific culture referring to something Canadian but as not being Japanese, which is reflected in the detachment to their ancestry and cultural ties. This detachment to their Japanese cultural and memorial ties is embodied in their relationship to their grandparents who cannot speak English well. Their narration of the past is bounded by two forces: one is the longing for filling up and rebuilding this relationship to the past and the other is the obligation to the community past of the forced assimilation which experience brought the discourse of multiculturalism to the redress movement.

Significant in this retrospective narration is the alignment of one's family past with the collective memory of Japanese Canadians in which the subjectivity of Japanese Canadian is represented as highly assimilated. In this form of narration, replacing the subject of "I" that was intended by my question asking their own perception like "how did you feel about yourself in that [white] neighborhood?", the Sansei participants repeatedly used unspecified "we", or group word the "Nisei" or "Sansei". Likewise, they frequently situate themselves in the third-person point of view introducing their other friends of a visible minority when they talk about the visibility of their own body. This depersonification of self in the narration is acknowledged as the preparation for the introduction of the collective memory that tells their own self. For example, in order to explain the familial background and the "Canadian" way of life, they had to introduce a philosophy of Japanese Canadians forged by the master narrative of the past, which has been described as the "shikata-ga-nai" attitude towards historical injustice. 
She [her mother], I think, in those days, they [the Nisei] tried not to make a fuss, not to disturb the water, no reaction, don't make a spectacle of yourself, because you always were a visible minority, don't say anything... She is a very positive person. very hard to stand up, very typical to Nisei, just let it go, just accept, worked out it okay, don't congregate like a ghetto. (Natalee)

Intentionally changing the subject from "she" to "they" and depicting her mother as a typical Nisei, she was able to align her family story with the master narrative of Japanese Canadian Nisei women in reference to the academic and popular literature. Alignment with the master narrative was apparent in all of my interviews with Sansei. The desire for the belonging to a collective sense of the history of Japanese Canadians was leveraged for the justification of the rupture of the Japanese culture, rather than the accusation of the perpetrator. They all showed their regret - not resentment - of the loss of their culture usually symbolized by the language loss.

I figured that they [the Nisei] just wanted us [the Sansei] to be a Canadian and Canadianized, and I don't think they need to send us there [Japanese school]. Most of the Sansei that I know hated going there. Also, most of those people I think though that they would take it more seriously. (Sophia)

In narrating their own life, they are urged to make sense of the loss of culture. In that sense, the internalization of the collective memory by the later generation is more geared towards an individual sense of coherence of the narrative of themselves in the continuum of that past, internalizing and reconstituting the subjectivity of Japanese Canadian that is intensely assimilated in Canadian society.

This perspective provides a critical insight into the fact that all the participants, including those who described their in-between status in the process of identity formation, addressed no prejudice and no discrimination. All of them denied any experience of being discriminated against based on their race or ethnicity.

We didn't really face any discrimination, an odd kid said something about being Chinese, for the most part, I don't feel like I faced any type of discrimination. I think was [thanks to] my parents, they just wanted to fit in, coming from being in the camp 
and coming out and told you cannot stay on the coast and you had to go. They just wanted to assimilate into the community. That's basically what we did. (Sophia)

This can be understood as a representation of their assimilated self on the continuum of the history of Japanese Canadians. This continuum of the time in their narration induces the success of the Japanese Canadian from their family pasts of assimilation. It is somehow surprising how they described their socio-economic achievement in their life, considering the economic challenges that their family had after WWII. Their attitude toward their current socio-economic status that can be inferred from their occupations is the naturalization and their naturalized success seems to be connected to cultural assimilation and their parents' hard work after WWII.

The Japanese Canadian high socio-economic status in the current society that a variety of statistics (see for example, Block \& Galabuzi, 2011; Lindsay 2007) show is described as the flipside of the ideology of assimilation. Through this reasoning process, the official qualification of skills most of the Sansei strived for is recognized as race-free and studying hard and excelling in math and science is thought to be a path to make their successful living. Although there does not seem to be an explicit expectation of their higher education and occupation, it still remains in an implicit manner.

We were all concerned about how higher marks were for getting into the university whether or not we are going. I guess there was an unspoken expectation we were all going where. (Patrick)

In that respect, their storytelling of the past as the assimilated Canadian is connected to the sense of the success in the current life, knitting a seamless storyline from their past to the present.

However, this seamless timeline is too strict to include all the diverse stories of Japanese Canadians. In that sense, they do not always tell their story in a way that conforms to the specific Japanese Canadian subjectivity. The created seamless timeline is disturbed by 
the longing for rebuilding the relationship to the past. While they refer to the "typical" Japanese Canadian history as resources to make sense of their own past, they introduce "untypical" or "rare" stories to break this rigid contour when they talk about their family stories. While Sophia insisted on no discrimination in her life several times during the interview as the "group story" of Japanese Canadians, she shared the story of her brother's experience of racial discrimination at the very end of the interview.

My brother, his wife's family was prejudiced against. They did not agree with her marriage with my brother. They are Caucasian, and they were kinda against their relationship because he is Japanese, or maybe because he is not Caucasian, I don't know. (Sophia)

Her confession of the racial discrimination demonstrates the multiple "selves" that emerge in telling the past. The research situation based on Japanese Canadian ethnicity urged her to speak on behalf of the Japanese Canadian Sansei group. She had to reject the notion of racism to perform her role as an assimilated self. At the same time, she had to reconcile multiple her "selves" at varying occasions conditioned by the interview. In this case, the desire for the connection to the family story drove her to speak out this story in an additional way in order to add another layer into the stories of Japanese Canadians.

Another attempt was made to represent their parents' resilience as compared to the victimized subjectivities of Japanese Canadians before WWII. Patrick talked about a newspaper article he found that depicted his father's play in a rugby game in the United States.

At that point [until he found the article], my understanding of things up to the war [the WWII] was very segregated. It was an interesting picture. It wasn't that segregated. He went off school to play sports somewhere else... It was a mixed team. In [the picture], like I mean, he may have been the one of the only Japanese on the team. I mean, I can tell from the picture. I mean, the guy he was stealing a ball from was obviously Caucasian. So that was definitely mixed. (Patrick) 
He selected this "new" finding of an individual who crossed the national border for playing sports to demonstrate an emerging individual with the agency over his father's life in the society that racialized people of Japanese descent. In this narration, he presents himself as an ignorant citizen swallowing a "dead memory". This story is leveraged against the history that utilizes the "dead memory" in the process of creating a singular understanding of the past. In that singular understanding, all the Japanese Canadians are labelled as submissive victims of racialization. As Dick argues in his case study of Sargent Matsui during WWI in search for the relation between collective and individual memories, storytelling in their own term "invites its audiences to draw on their experiences in generating their own understandings of the past and its significance" (2010, p. 438). The presentation of their own understanding of the past reveals the "homogeneous empty time" of historicism, created by the arbitrary detachment between past and present. From this perspective, the Sansei's storytelling of their family pasts is understood in the process by which they attempt to retrieve the arbitrarily deprived pasts by introducing diverse stories buried in the "homogeneous empty time".

Ijusha Nisei: Visibility as Japanese and becoming Canadian

Similar to the Japanese Canadian Sansei, visibility played a significant role in constructing Ijusha Nisei's self-image in their interview narratives. Three out of four interviewees (Charles, Kenji, \& Nozomi) described their childhood neighborhoods as predominantly white. Their sense of visibility is different from that of Japanese Canadian Sansei though in the particularity of the image of "Canadian" and "Japanese", the connection to the history of Japanese Canadians, and their family environment where they inherited the Japanese heritage and cultures. The particular image of the ethnic icon came from the development of the media industry that affected their sense of visibility in their childhood. The age gap between the Japanese Canadian Sansei and the Ijusha Nisei might explain 
different means to create social knowledge of race. Their sense of visibility derives from the cultural production of the iconic racial image in the media.

For example, Charles, who was raised in a predominantly white satellite city in the north of Greater Toronto Area shared his experience of "racism" in reference to the stereotype of an Asian male that a famous British caricature depicted.

When I was a kid, [I] remember that I said, that there was no positive Asian role model. So, I remember that kids teased me, teasing me and calling, you know, have you ever heard of Fu Manchu? No? So, Fu Manchu was a caricature of Asian ... of an Asian person. So they would be like, hey Fu Manchu. They were very racist, right? (Charles, Ijusha Nisei/Japanese Canadian Yonsei)

This storytelling indicates that the media production of the stereotypical Asian was already rampant and influential. This racial stereotype imposes a compulsory internalization of the subjectivity of an Asian male associated with a fool and an evil character. Additionally, this depreciation of human agency over the representation of themselves accompanies with a negation of his cultural roots as Japanese by pushing all the people who look Asian into a predetermined category. In this sense, inaccessibility to a counter Asian role model causes the depreciation of his cultural ties to Japan.

Popular depictions of the Asian subject as evil or/and a fool mirrors the image of Canadian as the counterpart. The media transform these ethnic subjects into those that people consume as a form of entertainment. In this commodification of ethnic subjectivities, people seek access to represent themselves in a positive way with these resources that became accessible through media. The materialization of ethnic subjectivities induces their desire for aligning themselves with that counterpart image. In this sense, to Ijusha Nisei, "Canadian" is recognized as something they become and perform in the exploration of the cultural resources indicating this positive image. Noting media influence, Kenji, who was also raised in a white 
neighborhood with a small visible minority population, addressed his desire to be Canadian and hatred of being Japanese during childhood.

I really wanted to be Canadian, but to me Canadian was white. Your name is Michael, Jason, or David, you know, that's what your name was. And you played hockey, and you ate macaroni cheese every day, peanut butter jerry sandwiches and that's what I wanted. (Kenji, Ijusha Nisei)

His desire to be Canadian and hatred of being Japanese indicates his self-awareness of belonging to the Japanese culture. In the course of the interview, he marked off the Japanese environment in his family. His parents only spoke Japanese to him and before he entered a public school his first language was Japanese. Every New Year's day, his family watched a specific Japanese TV program and held a New Year's party with other Japanese families. He also narrated how his Japaneseness - such as obento his mother made for lunch at school, his Japanese name that is difficult for a school teacher to pronounce, and so on - pointed him out in a class where most of the classmates were "Caucasian". The frequent representation of his Japanese culture comes from the lack of knowledge of his parents on Canadian, or Western culture including language. The Japanese way of upbringing was the only way for his family. He speculated that although he asked his parents to let him play in a hockey team many times - which was one of the ways for him to satisfy his desire to be Canadian - his parents declined his plea because they did not understand the English registration form. Reflected on their dependence on cultural resources in the Ijusha community, his parents instead sent him to a variety of lessons such as piano lessons, a Soroban school, judo lessons, and a Japanese language school, which lessons were provided by the Ijusha community and the Japanese Canadian community.

He described this situation as ironic because while his father left Japan because he disliked Japanese cultural values and parents were indifferent towards passing down Japanese culture in the family environment, they ended up imprinting some of these cultural values on 
him. In particular, he pointed out the Japanese norm of the marriage relation. According to this norm, a father should be the only breadwinner and work without thinking back to family issues and a wife should do the housework. The lack of available settlement services and husband's aid to raise him up and the closed network in Canada isolated his mother from Canadian society and made her suffering depression. Consequently, this social isolation drove her to rely on the sporadic family supports from Japan.

The sense of visibility as Japanese despite their desire to be accepted as Canadian, compose the similar in-between identity to that of the Sansei. This in-between status is grounded in their own perception of self by their additional efforts to entitle themselves to be Canadian. This effort is acknowledged as unnecessary and extra in comparison to their "Caucasian" schoolmates, to whom to be Canadian is just a way to be. Nozomi, an Ijusha Nisei, who was raised in a neighborhood where she was one of only a few Asian kids, tried to hide her Japanese signifiers on a variety of occasions where she interacted with her "Caucasian" school friends. She only spoke in English to her mother in school although her mother might not understand everything that she said because of her mother's imperfect English skill and that is why she usually spoke in Japanese at home. Food was another obvious signifier that she had to hide from her school pals. She remembers that whenever she invited her friends to her home for a sleepover, she asked her mother to order pizza instead of usual homemade dinner. This performance to attest her belonging as a "Canadian" ironically sharpened her sense of unbelonging.

Being narrated from the perspective of the present, the sense of difference provides narrators' understanding of their past in comparison to the present. Immediately after Nozomi talked about her sense of visibility as a "Japanese", she continued to talk about how she currently feels comfortable with showing these cultural signifiers. She ascribed this comfort to the current social acceptance of the Japanese culture based on multiculturalism, which is 
mostly acknowledged as the surging popularity of Japanese food and pop-culture. In her account, the sense of visibility is recognized as a reflection of the social tendency to exclude the foreign culture and the social designation of Japanese culture as the foreign culture is ascribed to the social ignorance about Japanese culture. The acceptance of her body as a member of society is achieved through the process of knowing culture, elicited by the ideology of multiculturalism.

However, Nozomi's narration also indicates the limitation of the multiculturalism ideology in which familiarizing Japanese culture has been conducted through the materialization of Japanese culture so that people can entertain it as a tangible form. The acceptance of Japanese culture through the consumption of its fetishized form increases the cultural "tolerance" of Canadian society. But it might not be directly translated into the insurance of cultural citizenship of Japanese Canadians where the exchange of cultural knowledge opens the dialectic engagement of learning each other's perspective. Her narration questions the perspective of this ideology of multiculturalism because what culture is tolerable in Canadian society is based on the possibility of the consumption. She confessed in the interview that she was passively involved in the talk of parents' love stories in her childhood and is still hesitant to talk about it because her parents got married through the family marriage arrangement. She touched on the fact that even her closest friends would not know this. The fear of expressing a part of her family story derives from the expectable immediate rejection and thereof cultural exclusion even in the society embracing multiculturalism.

As is the case for Japanese Canadian Sansei, the in-between identity of Ijusha Nisei is also furthered by the stay in Japan and the encounter of Japanese people. Charles talked about the "bizarre" feeling that he felt when he was "anonymous" in a city in Japan. 
I just felt for the first time, anonymity. I was not different or special. [Be]cause when I was that age, I'm average height, I'm average looking, I look very ordinary. So, in Japan, it's very weird that if I just step beside, no one looks twice at you. Like it was very bizarre. (Charles)

The sense of anonymity that he felt for the first time in Japan is reflected in the sense of visibility in Canada as a person who has a different or special body. While he narrated this feeling of anonymity in a pleasant tone, this bizarre but comfortable sense of anonymity is broken when the occasion came where he had to speak in Japanese although he cannot.

When I went into stores, people would think I would be rude. Because they greeted me, I wouldn't say anything. So they would think I was being rude. Then my friend would have to explain, "Oh no, he doesn't speak Japanese". And then they would think I was mentally handicapped. Then they would be like "Oh, I see. Is he handicapped?" And my friends [said] "no, no, no. He is Canadian" (Charles)

The assertion of being Canadian is acknowledged as the only persuasive tool to explain this "weird" occasion in which he felt culturally excluded from Japanese society. This experience demonstrates his representation of the ethnic identity that is Canadian first and Japanese second.

The story of Ken, who is the only participant who did his interview in Japanese, typified the sense of hybridity that is more gravitated toward Japanese cultural values. As the sense of visibility varies within the Sansei, here is a difference within Ijusha Nisei in the meaning to be different. Compared with the Sansei participants in this interview, Ijusha Nisei were sometimes raised in the more multiethnic neighborhood. The interview with Ken, the youngest Ijusha Nisei who was born in 1989 and raised in the north part of Toronto, symbolizes this neighborhood change. He lives in the northern part of Toronto where the people with multiethnic backgrounds live. He repeatedly remarked on the evenness of the racial profile of the school children, his friends, and members in extracurricular activities in a way that attests to the ideology of multiculturalism in his neighborhood, in which the ideology is understood as equal access to social group regardless of race. In the multiethnic 
social condition, the sense of difference based on racial appearance loses its significance, but instead the lack of transnational connection makes him feel himself as "normal" with a negative connotation. This sense of "normal" was accentuated as that multicultural neighborhood welcomed more Chinese and Korean immigrants.

仲の良いやつはトロント育ちだけど中国に地元がある。俺はそこが育ちで地元って いう、なんか、いたってノーマル。

Close friends, although they were raised up in Toronto, have a "home" in China. To me, Toronto is the place where I was raised and a "home", which is why I am "normal". (Ken, Ijusha Nisei, translated by Author)

The normalization in the oral history of Japanese Canadian Sansei was observed in their narration of their subjectivity assimilated into the Anglo-Saxon culture. By contrast, he developed another sense of normalization that required him to "stand out" as the epitome of multiculturalism. He indicates that this social expectation of embracing cultural roots increased his sense of comfort in a Japanese school. This sense of comfort and his parents' social network within the Ijusha community led him to the active involvement in the Ijusha community - such as part-time work in J-town (a Japanese shopping mall) and a Japanese sports club in Toronto - where people speak Japanese most of the time. This alternative sense of normalization that legitimates the difference in the multicultural society drove him to explore something special along with this ideology. That is how his values and attitudes towards the ethnic identity converged into the Japanese cultural values as he became more exposed to Japanese people during his stay in Japan and his frequent involvement in the Ijusha community.

However, this does not simply mean that he narrated his life as a Japanese. Conversely, he has a strong affiliation to Toronto as home by saying that he would like to contribute to the city of Toronto somehow in the future. While he felt at homes in the Ijusha community of Toronto, the encounter of Japanese people, particularly Ijusha Issei, Japanese 
students, and temporary workers staying in Canada with the working holiday visa, made him aware of how different he was from people from Japan. For example, he remembers he got angry when his Japanese friends in the sports club pushed the age-based Japanese hierarchic norm to their relationship. His friend mentioned how as the youngest in the group, he was supposed to behave in front of those older than him. This unfamiliar norm that is incongruent to his way of thinking nurtured in Canada amplified his sense of isolation in that group. This notion of difference was accentuated during an a few weeks stay with his family in Japan every four years. In the diaspora studies, the repetitive return to the home country is conceptualized as a family strategy that develops the ethnic belonging to the home country (Duval, 2004). Despite his description of this family's periodic visit to Japan as a "return", he denies the affiliation to Japan as "home" and instead described this occasion as the encounter of the Japanese as a different group.

\section{Social Assignment of "otherness" and the self as a representative of multiculturalism}

The attempt to rediscover their cultural roots is predicated on the freed selection of who they are against the social assignment of the subjectivity essentialized by race and popularized by Japanese culture. The freed self, embodied through the narration, is observed in their family stories as well. For example, Kenji described his family immigration as a way to live their own lives freed from the strict norm of Japanese cultures such as the hierarchical organizational structure based on seniority and educational background. As Minamikawa (2015) indicates, the individualization of the sense of self can be seen. Individualization is a product of the increasing uncertainty because of the decrescent regulation by the social institutions and statutes such as nation, family, hierarchy, church, corporation, school and so forth, and a strategy to internalize that fluidity and uncertainty within themselves as a thing that "they control". 
Combined with the ideology of multiculturalism, the individualized meaning of being Japanese is positively conceptualized as how he lives in Canada rather than what he is in Canada.

I'm glad that we live in a country where we can embrace our roots, Japanese roots, but still have an identity as Canadian, more Canadian, accepted now to be multicultural, back them more like, it was not bad, but it was like Canadian is white... if back then if you could ask me what I was, then I would say I'm Japanese because I wanted to be Canadian, but now I am 100\% Canadian. (Kenji)

As he indicates, to be an agent of the ethnic identity construction means to be " $100 \%$ Canadian". This clear awareness of the agency that internalizes the complexity and multifaceted social relation in the self-identity is also performed in the narration of his own life history. Touching on the stereotyping and generalizing force in both societies of Japan and Canada, he told his sense of self in a way to perform his agency freed from the social binding to what he should be. Regarding his job of firefighting, he remarks that he is the only Asian out of 200 workers in the fire department and gives a positive recognition to be different on that occasion.

That's a good difference I think, because I think especially Asians, not, you know, Japanese, Korean, Chinese, whatever, we get stereotyped especially in North America that, you know, Asian people are good at computers, they good at math, they do IT jobs or research jobs. There Asians are not firefighters, not policemen, not construction workers, they don't do jobs like that. There is that stereotype which is mostly if you look around true. (Kenji)

This performance of agency is also directed towards the diplomaism and the stereotyped quality of life that pictures "a good life with a good job" in Japan.

What the Japanese culture puts an emphasis on is what is a good job and what is a bad job. Even when my grandparents were still around when I became a firefighter. They didn't like it. ... To them, why didn't you study more [Laughter] to get a better job, right? (Kenji)

The narration of their occupation and the decision-making with regard to their occupation demonstrate different thoughts from those of Japanese Canadian Sansei. Although 
it is uncertain whether or not Sansei participants regard as a resource the Asian stereotype of being good at science and math and having professional jobs, their occupations actually reflect this stereotype. Regardless of their feelings to be situated as the actual representative of this stereotype, they in that situation naturalize their current life. By contrast, the Ijusha Nisei are more aware of their decision-making in regard to their career path and how their life cannot be described in the stereotypical subjectivity of Asians. He speaks of his life history where his identity is constructed as the reflection on how he lived, lives, and will live. Through the reification of the self as an agent of one's life, the ethnic identity of being Japanese Canadian is presented as that he chose.

However, the expression of self is not always freed from the racial exclusion from Canadian society. As opposed to their national identity as Canadian and their feeling of cultural inclusion, the question of "what is your background" and "where are you from" makes them feel racially excluded from Canadian society, expecting a specific acceptable answer.

I know they were trying to have a small talk, but if my wife [, who is Caucasian,] was asked that question, someone asked her, 'what's your background?', she said I'm Canadian. That began the conversation. That won't be for me. That is not an acceptable answer. I feel I am accepted in Canadian culture, but still, a part of, a little bit can't be Canadian because I don't look Canadian. (Charles)

Just going out to a place, and people do not automatically think you are Canadian, you know. They are like, where are you from? I'm from Toronto. No. Where are you originally from? I'm like originally from Toronto. [Laughter] (Kenji)

The Sansei participants reacted to this type of question asking the legitimacy of their belonging to Canada, looking for the self as the continuum of the past. By contrast, Ijusha Nisei participants are prone to internalize the power over this social assumption by placing people intruding their sense of self as those ignorant living in the "past" and "obsolete" 
society, and themselves as those living in the "present" as a representative of multiculturalism.

Sometimes it's a little bit about educating. They just don't know because they grew up in a city like [city's name] where there are not a lot of Asians and multiculturalism. They don't know any different, right? Sometimes just teaching them. (Kenji)

The reverse of the structure in the question - the past structure between Asian as objectified "other" and "white" in the power of the social assignment of who they are- is attempted by asserting the advent of a new period associated with the multiculturalism. The idea of multiculturalism internalized in this framework is not based on the cultural tolerance of Canadian society but based on the communicative space in which citizens can communicate and exchange their own perspectives, inducing mutual learning process. In this framework, his body of the Japanese descent authenticates his status of an "educator" by providing the multicultural experience and cultural heritages.

Based on this idea of multiculturalism, ethnic identity as "Japanese Canadian" is acknowledged as what they perform and its legitimacy of performance of ethnic identity is predicated on the prospective communication that induces the mutual learning. For example, Charles explores his Japanese part of ethnic identity in his expression of "homage" to the Japanese culture. This performance of paying "homage" is conducted in his everyday life such as cooking and buying Japanese food, signing his autograph by Kanji (Chinese characters), and raising his children based on the Japanese discipline of "humbleness". This seemingly trivial gesture of paying "homage" to Japanese culture is the way to maintain his sense of belonging to Japan based on the expectation of the cultural acceptance and the communicative space in the multiculturalism. In this conceptualization, ethnicity is regarded as a symbolic resource in their identity politics to demonstrate the agency that is leveraged for the creation of the communicative space where civic obligations to "learn" each other's perspective are practiced. 


\section{Reifying myself as the subject of interview}

In the process of oral history interviews, this project encountered a methodological characteristic of oral history approach. The interviews proceeded, inducing interviewees to situate themselves in various occasions where they play different roles of multiple selves according to the request of the present that urged them to make sense of the meaning of the past. That ongoing process also involves the researcher in the construction of their narration through the iterated interactions. I was urged to share my "Japanese" experiences that were piqued by interviewees" understanding of "Japaneseness" that their past experiences molded. In the oral history interviews, my standpoint and personal and emotional relation to this research was revealed by sharing these experiences with the participants. In the process involving a researcher in the oral history as an "I" who has specific experiences relevant to the topics of their narration. This revealed image of "I" was incorporated into their oral history as a "mirror" of their sense of "otherness" epitomized by their own experience of "Japaneseness". My visible cues such as my accented English, typical Japanese body language and behavior, and the way of dressing myself were drawn into the narration as a mirror of Japanese "otherness".

This representation of myself as the Japanese "other" partly broke the pedagogical authority as a researcher and invites their inspection into my own experiences as "Japanese". The reverse of the interview structure between participants as information-donors and a researcher as an information-taker sporadically took place when they talked about specific topics. These specific topics are of significance in their understanding of fluid, multiple, and ambivalent identity as "Japanese Canadian". The following section delineates what specific subjectivities of "Japaneseness" I presented in the oral history interviews and how different they were in the oral history interviews with the Japanese Canadian Sansei and the Ijusha Nisei. 


\section{$\underline{\text { Japanese Canadian food: Connection to the past and assimilated self }}$}

In the case of interviews with Sansei participants, I was situated as a mirror of "otherness" associated with the Japanese culture they lost. This "otherness" was associated with the "foreign" subjectivity that the racially exclusionary discourses created and thereof the object they had to deny to validate a sense of "Canadian" they obtained through the assimilation process. However, at the same time, it was also the key to rebuilding the disconnection to the Japanese culture. This ambivalent attitude is observed in their narration of Japanese Canadian food.

To Sansei participants, who lived their childhood as a "Canadian" in the white neighborhood, food is the exclusive medium through which they could feel the connection to the Japanese culture and their ancestors. The question about Japanese food is, in one way, geared toward the testament of their connection to "Japaneseness" through me as an authentic authority on Japanese food. While describing the Japanese Canadian cuisines they had in their life, they call for my nods or words of acceptance by frequently checking my response. This is their attempt to rebuild the loss of connection by excavating the experience in their own past that is connected to Japan-further to their ancestors.

At one point, this testament process incorporates the hiking popularity of Japanese food in Toronto in a way that demonstrates the social acceptance of the Japanese culture. Interpellation of my stories of contemporary Japanese food exposes them to another sense of authenticity of Japanese culture — which is a synonym to the contemporariness of the Japanese culture revealed through my narration. In that sense, sharing stories of Japanese food is not just reaffirming their connection to their cultural background of Japan. But through this interaction, they attempt to avail themselves of agency over the Japaneseness attached to their own ethnic identity. In other words, they explore access to the Japaneseness objectified through my migrant body. 
This exploration was always followed by the negation. They rejected the immediate connection to that "Japaneseness" through me right after the testament. They distinguished "Japanese Canadian" food from the "authentic" Japanese food buttressed by the sense of contemporariness. In their account, the Japanese Canadian food is associated with the connection to the nostalgic concept of Japan in the past. This negation is their expression of belonging in Canada, indicating the historical time that their family spent on establishing a new form of Japanese food. In this negation, they introduced their family story about the food. They narrated the process of the Canadianization of Japanese dishes in an unfamiliar environment where typical Japanese ingredients were inaccessible. The story of the Canadianization legitimates the Japanese Canadian food as the "transplanted culture" in Canada to represent their Japanese Canadian identity.

This case demonstrates the performance of the narrator in constructing their identity in the narration of their personal organic memory. As Olick \&Robbins (1998) delineates, using the "organic" memories, they represent themselves or their family as the first-person who possess the memories. As such, the recovery of the forgotten past is achieved in the food history involving me as "other" that bridges their ancestral connection that had been longed for since the redress movement and at the same time should be rejected to create a sense of legitimacy of their organic memories that delineate their Japanese Canadian identity. In this attempt to redefine the Japanese Canadian, the Japanese food that is literally imported from contemporary Japan, turns into the objectified symbol of "otherness". This rejection does not mean complete detachment to the Japanese culture. Instead, by rejecting the otherness that is reified through my body, they negotiate for the agency over their identity that is historically grounded in Canadian society. This process of identity formation is their representation as Japanese Canadians through the validation of the transplanted culture of Japanese Canadian 
food and the resistance against the consumed otherness assigned to the contemporary Japanese food in the current society.

\section{Bridge between the Ijusha Issei and the Ijusha Nisei}

By contrast, in the interview with Ijusha Nisei, my role as a mirror of a part of their ethnic identity is called for to bridge the cultural gap between the Ijusha Issei and Ijusha Nisei. The comprehension of the tacit knowledge through me is intended according to individual needs in identity politics. For example, Charles. shared a story of his "emotional distance" to his father because of the different fatherhood between Western and Japanese culture.

His parents came to Canada in 1979 after his father got married to his mother, who is Japanese Canadian Sansei and taught English for adults in Japan. He speculates that no cultural space for the Ijusha Issei in the 1980s in Toronto drove his father to follow the assimilation path as a new immigrant to Canada. Regarding the language education in his family, his father did not teach him Japanese and he now cannot speak or understand Japanese. His father's English is still not good enough to convey the nuances of his thoughts. Unlike other Ijusha Nisei participants, his family did not visit Japan regularly because of his father's defective relationship to his family in Japan. In this environment, he internalized the Canadian cultural norm of fatherhood in terms of the expression of emotion. This incongruent fatherhood and entailing miscommunication in his family created the "emotional distance" between him and his father. This is one of the examples in which the difference between the responses he expected and that his father actually showed.

I remember one time in university, I got two "A"s and two "A+"s. and I was like, oh he is gonna be so proud of me. I showed it to him, and I was like Oh look at my grades! He said oh those must be easy courses. [Laughter]. So my mom is always saying like that's because it is Japanese [way]. I think a lot of excuses my mom would say. (Charles) 
Although he narrated this talk with a hilarious tone as if he played a comedy monolog, this "comedy show" that actually happened to him arouses the confusion in the relationship to his father. This confusion is deteriorated because of the language barrier that inhibited the verbal communication between the two, which required the mediation by his mother with her culturally "right" understanding. It is on this occasion that he asked me what my father was like. I started sharing my own experience with my father as an analog to his story. I told him that I did not have regular contact with my father in my childhood because he left for work before I woke up and came home after I went to bed, and he was not good at expressing his emotion directly and honestly, with much less saying of "I love you". From my experience, this occasion was understandable and imaginable. Following this memory sharing, I explored the non-verbal cues that his father might have signaled to him to express the same feelings that he expected. After looking for the key in my experiences to reconnecting his "emotional distance" to his father, he noted "I did not have Japanese friends. if had friends with you, you would tell me like no, no, no, that's normal. Don't worry. Even you tell me that now, makes me a little bit better".

This dialogue between us is more than just an exchange of information. In this dialogue, he tried to bridge the "emotional distance" to his father by reifying me as a navigator of the Japanese cultural knowledge that his father internalized in Japan. This role of the navigator is based on my own "otherness" attested during the interview like the interview of Japanese Canadian Sansei. In this process, demonstrating my standpoint in this research and assigning me a role of contributor to their oral history, this sharing of authority over oral history enabled the research to look into his emotional and cultural cost that he had to pay by fitting in the Canadian society. He speculated that his father would regret the decision to bring him up by urging him to fit into the Canadian society by not teaching him Japanese. At the same time, he himself regretted his inability to have fully developed communication with 
his father because of the language and non-language barrier, leading to the creation of "emotional distance". He mentioned in the very last of the interview that a part of the reason why he sends his daughter to Japanese language school is his way to pay "homage" to his cultural heritage and to compensate the loss of connection to his father.

\section{Conclusion}

This research project sets out to reveal the complexity of individual ethnic identity formation among the Sansei and the Ijusha Nisei through the oral history approach. This approach invites the researcher to the "double-edged site". In that discursive space that is repeated in their everyday lives, the racialized subjectivity is at work (re)constructing the negative and unsolid in-between identity of Japanese Canadians. On the other hand, socially, politically, culturally, and historically situated in Canadian society, narrators negotiate social inclusion against the reproduction of the essentialized subjectivity based on their physical appearance.

The visibility of the Japanese descent assigned and designated to their body and cultural signifiers compose the in-between status of ethnic identity formation. Both of the Japanese Canadian Sansei and the Ijusha Nisei participants attempted to explain and reconcile their sense of in-between in their oral history. Faced with the setback of the social inclusion process, the Sansei and the Ijusha Nisei differently negotiated the legitimacy of their national belonging, in other words, cultural and racial citizenship. The research findings indicate what ideas of multiculturalism are transmitted to Japanese Canadians in the process that constructs their ethnic identity. If multiculturalism is to be understood as cosmopolitanism that Stevenson (2003) refers to, the communicative space should be created in a way that "dispenses with national exclusivity, dichotomous forms of gendered and racial thinking, and rigid separations between culture and nature, and popular and high culture” (p. 333). 
The Sansei in this research study are heavily influenced by the collective memory of Japanese Canadians. In the process by which they utilize the collective memory as a resource for the construction of individual ethnic identity, the subjectivity of Japanese Canadians is characterized as culturally assimilated into Canadian society and, therefore, socially and economically mobile upwardly. The negotiation of social inclusion based on this uniformed collective memory delineating assimilated subjectivity - rather than undermines the exclusive framework based on a dichotomous form of racial thinking - epitomizes this very exclusive framework based on race by forcing Japanese Canadians to align their diverse experiences with the uniformed history and thereof to internalize the assimilated self as a basis of this negotiation. In this framework, I argue, Sansei participants feel obliged to assimilate into the uniform group story in which their ethnic identity is paradoxically enacted by performing the cultural and structural assimilation into white Anglo-Saxon society despite their individual longing for the connection to the cultural, familial, and ancestral ties to the Issei and Nisei generation.

However, the internalization of the uniform history does not provide the communicative space where their diverse stories can be included and heard to the public. At this juncture, they turn back to the capability of the collective memory that can hold diverse stories. The Sansei showed another strategy for social inclusion in their ethnic identity formation. In this framework, although they are oriented to the past to legitimate their negotiation as well, the negotiation itself is predicated on the possibility of multiple pasts that the collective memory conveys. This different perspective on the past allows diverse stories to emerge in the oral history interview by enhancing the agency over their identity politics. They introduce organic memories of themselves and their families into the narration. The organic memories they introduced are nuanced, contradicting, and multiple. Through the organic memories, they are liberated from the obligation to the uniformed history and 
allowed to create their own understandings of the past. Based on Stevenson's account of cultural citizenship, I argue that this possibility of the different and diverse understandings of pasts are the basis of the communicative space where people are urged to learn each other's perspective rather than swallow others' subjectivity moulded by the "dead memory".

However, this way of negotiation based on the theoretical concept of collective memory and organic memory seem inapplicable to the Ijusha Nisei, who and whose family do not have direct or subjective experiences of the historical injustice. Actually, Ijusha Nisei participants in this research study feel - rather than the pan-ethnic affiliations with their coethnics, Japanese Canadian Issei, Nisei, and Sansei - the detachment to the earlier Japanese Canadian community. The limited accessibility to the organic memories of the historical injustice directs them to explore another form of negotiation for social inclusion. In this other framework, they are prone to express themselves as representative of the multiculturalism that Canadian society embraces. As Minamikawa (2015) indicates, this can be understood as the propensity of people in the consumerism society to individualize the meaning of identity in a way that internalizes the uncertainty and complexity by creating their own meaning based on aesthetic criteria.

From this perspective, multiculturalism provides the aesthetic criteria for the "better" way of life. This conceptualization of "better" way of life is not simply translated into the economic success, but rather predicated on the freed agency over their life against the social assignment of the essentializing subjectivity. In that sense, the aesthetic criteria invite the subjective-oriented identity formation that provides a way to internalize external forces of essentialization. Through this process, they attempt to internalize the power over the stereotype of ethnicity by placing people intruding their individualized identity as those "ignorant" who live in the "obsolete" society. Their experiences of being othered and their Japanese cultural heritage are transformed into assets for the education to those "ignorant". 
The transformation of the meaning attached to experiences of being othered capsizes the hierarchic structure composed by the consumed, controlled, and excluded "other" and the dominant "whites" in power. They construct alternative structure in their narration that entitles them to be a "multicultural educator at present" and that describes those heavily depending on the essentializing force as those "ignorant learner". This representation of their ethnic identity is predicated on the communicative space that Stevenson's concept of cultural citizenship confers. The social phenomena that invites the activation of this cultural citizenship with which "the public is capable of learning from one another's viewpoints" (Stevenson, 2003, p.336) are observed in some narrations of Ijusha Nisei participants such as the case of Kenji.

Despite the potential of the multicultural ideology to create the communicative space, the research findings also inform another aspect of the multiculturalism ideology that Canadian society practices. This research study indicates that although the rapidly increasing visibility of Japanese landscape in Toronto can be regarded as the implementation and reification of the multiculturalism in Canada, this might end up fetishizing the Japanese culture in a form of consumption and entertainment of the "exotic" without educating the cultural acceptance to the public. In this form of multiculturalism, mainstream Canadians can tolerate the influx of different cultures because here is the expectation that they can control them through the consumption. On the other hand, it does not develop the cultural acceptance of the mainstream society because the consumed "exotic" culture is just regarded as an object and does not necessitates mutual understanding. This limitation is represented by the Sansei's negation of the contemporary Japanese food - represented through my symbolical "otherness" - as a factor that constructs their ethnicity in fear of the objectification of their ethnic identity and Ijusha Nisei's perception of what Japanese culture is acceptable to the mainstream society as in the case of Nozomi. 
The in-depth description of the oral history of Japanese Canadians demonstrates the complex and unfinished process of the ethnic identity formation of Japanese Canadians and their negotiation for social inclusion in that process. Collective memory has been utilized as the momentum for the politics of recognition by minority groups all over the world with the experience of political and historical injustice. Academic discussions of cultural citizenship that have been enhanced or deteriorated by the concept of collective memory do not fully develop its potential for the cosmopolitanism society. This research proposes that more empirical studies should be done, considering how collective memory affects the ethnic community over generation and beyond in-group different experiences in terms of ethnic identity formation and how the politics of recognition utilizing collective memory influences the social inclusion and exclusion framework.

\section{Limitations}

The multilayered stories that the Japanese Canadian Sansei and Ijusha Nisei narrated during this project show themselves as transient and multiple selves according to social, cultural, historical, and political conditions rather than the singular established self. With the focus on individual ethnic identity formation of the Japanese Canadians, this research project touched on the nuanced self-representation, torn between the essentialized self that is suppressed by the racializing discourse and the self enacting the ethnicity that creates the discursive space for their own understanding of ethnic identity in individual accounts. As these complex conditions indicate, this research is not intended to generalize the population of the Japanese Canadian Sansei or Ijusha Nisei. In addition to the acknowledgement of the objective of this research, it is also imperative to note the limitations derived from the framework and the methodology of the research.

First, due to the recruitment of the small number of participants with the snowballing sampling through the people of community contact, the participants are limited 
to a certain group in the Japanese Canadian community. This research had the Sansei and Ijusha Nisei participants only from a specific class category. As Oikawa (2012) proposed, research in Japanese Canadian studies including those from other working class would be informative for the understanding of different aspects of the community.

Second, as people of community contact who introduced Japanese Canadian Sansei are highly involved in the JCCC, the Sansei participants narrated the active involvement in the JCCC events and workshops. As this active involvement might be reflected in their marriage within the Japanese Canadian community. Three out of the four Sansei participants were married to another Sansei. Considering the higher percentage of intermarriage in the Sansei population, they are the particular population that would have more cultural resources from or cultural orientations to the Japanese Canadian community. In terms of the production of the assimilated self, it is interesting to note how and to what degree involvement in cultural and community events affect the awareness of ethnic identity and the negotiation for social inclusion in relation to the collective memory of Japanese Canadians.

Third, although the recruitment process is open to people having the multiethnic background, this research is limited to those who have both of parents are the Ijusha Issei or Japanese Canadian Nisei or Sansei. As the data in this paper shows, the high intermarriage rate of the Sansei population is prominent. In addition, Kobayashi (2002) shows that women who married white Canadians account for the two-thirds of the recent immigrants from Japan, therefore the increase in the multiethnic population will be accelerated in the Japanese Canadian community. The research on the ethnic identity formation of and the influence of body politics on those who have been intermarried and those who are multiethnic will provide fruitful information. 
Fourth, although this research recruited both men and women, the analysis does not delve into how gender influenced people's construction of their in-between identity and performance of ethnicity. In particular, Ijusha Nisei participants mentioned the intersectionality between ethnicity and gender in their interviews. They talked about the differences in the subjectivity of Asian women and men and the replicated Japanese gender norms in their family environment. The intersectional research between gender and ethnicity is an interesting insight into how the family strategizes and conduct the intergenerational culture transfer and how the sexual subjectivity is connected to or levered against the racial and ethnic subjectivity and vice versa.

Fifth, this research project discussed the influence of the social assignment of race and ethnicity. Considering the current scholarly discussion of the model minority discourse as a new type of racial discrimination (Chou, 2008), the analysis suggests that the subsequent research should include how their notion of success embedded in the assimilated self influenced their identity formation and how this model minority stereotype or breaking this stereotype is performed in relation to the process of identity formation. 


\section{Appendix}

\section{$\underline{\text { Interview protocol }}$}

Time of Interview:

Date:

Place:

Interviewer:

Interview:

Questions:

Questions about demographic data such as name, age, email address or/and telephone number, education level, ethnicity with which they identify themselves, Gender/Sex

$>$ What is your name?

$>$ When were you born?

$>$ What is your gender identity?

$>$ What is your educational background?

$>$ What is your marital status? Married Single, never married, widowed, etc.? Or have you married in your life?

$\diamond$ What is your partner's ethnicity?

$\diamond$ Do you have any children? If so, how many? When? Where were they born?

$>$ What is your occupation?

$>$ Do you identify with a religious group or faith?

Family in your childhood

$\checkmark \quad$ Where did your family live when you were born?

$\checkmark \quad$ Where in Japan is your family from?

$\checkmark$ Do you have any siblings? If so, how many siblings do you have?

$\checkmark \quad$ In what year did your family or parents come to Canada?

$>\quad$ Did they come to Canada alone? Or with partner or family?

$\checkmark \quad$ Where did your family live when they first came to Canada?

$\checkmark \quad$ Where or what cities have you lived in?

$\checkmark \quad$ When and how did you or your family come to Toronto?

$\checkmark \quad$ Did you or your family come to Toronto by yourself, with a partner, or with their child?

$>$ What was the first impression of Toronto when you came (if they move to Toronto)?

$>$ Do you have any interesting stories that happened while you were traveling?

$\checkmark \quad$ Could you describe the house where you grew up?

$\checkmark \quad$ Could you describe the neighbourhood where you grew up?

$\checkmark \quad$ What was your father and mother's job?

$\checkmark$ What were your family's economic circumstances?

$\checkmark \quad$ What activities did your family do together?

$\checkmark \quad$ What is your family's religious background? How was it observed in family?

$\checkmark \quad$ What challenges and opportunities did they have in their lives in Canada?

$\checkmark \quad$ Did you have relatives close to your house?

$>$ Where did they live?

$>$ How often did your family contact them? 
$>$ When did your family meet them?

$\checkmark \quad$ What language was spoken in your household when you were growing up?

$\checkmark$ How would you describe your relationship with your mother/father/ etc?

$\checkmark \quad$ What holidays did your family celebrate in childhood?

$\checkmark \quad$ What holidays are the most important?

$\checkmark \quad$ Were there special family traditions, customs, songs, foods? Do you still celebrate the same things?

Neighborhood

$\checkmark$ Could you describe the place - urban neighborhood, small town, rural community, suburb, etc. - where you grew up?

$>\quad$ Is there Japanese community around your neighborhood?

$>$ How has it changed over the years?

$>$ What brought about these changes?

$\checkmark \quad$ What community traditions are celebrated today?

$>$ how long have they been going on?

$>$ How have they changed?

$>\quad$ Why are they important to the community?

$>$ What do you think is the future of these traditions?

$>$ What are the challenges and opportunities?

Socialization in education system

$\checkmark \quad$ What school did you go to? What did you like about the school? Or dislike?

$\checkmark$ How many Japanese Canadians or children from visible minority were in your class?

$\checkmark \quad$ What was your nickname?

$>$ What did your nickname come form?

$\checkmark \quad$ Who were your friends? What did you do with your friends?

$>$ Did you have close Japanese Canadian friends in school?

$>$ Did you have close friends who are not Japanese Canadians?

$\checkmark \quad$ Who was your close friend in school?

$\checkmark \quad$ Did you have Japanese Canadian neighbors when you were a child?

$\checkmark \quad$ At what age did you begin dating? Who did you date in your school days?

$>$ What kinds of activities did you do on dates?

$>\quad$ What was your family's attitude towards your dating? Did they have any expectations?

$\checkmark \quad$ What were different groups in your school? Could you elaborate?

$>$ Which group did you belong to?

$>$ How do you think that you were perceived by other groups?

$\checkmark$ Do you have memorable teachers? How did the person influence you?

$\checkmark \quad$ What extracurricular activities did you do during school days?

$\checkmark \quad$ What was your favorite food during your childhood?

$\checkmark \quad$ What was a challenge you face in your school days?

$\checkmark \quad$ What were your plans after school? Work or more education? Why?

$\checkmark \quad$ What was the expectation of your parents about your education?

$\checkmark \quad$ What did you major in your college days? And why?

History of Japanese Canadian

$\checkmark \quad$ Where did your family live when the WWII took place?

$\checkmark$ How did your family respond to the governmental order? 
$\checkmark \quad$ Have you heard any stories about the WWII and internment from your family, if so what is it like?

$\checkmark \quad$ What was your first thoughts when you learned Japanese Canadian history?

Cultural heritage

$\checkmark \quad$ What languages do you speak? Do you speak Japanese? Or have you learned Japanese?

$>\quad$ When and why did you start to learn Japanese?

$>$ Do you speak a different language in different settings, such as home, school, or work?

$\checkmark \quad$ Did you go to Japanese language school?

$>$ Could you elaborate what you did in Japanese language school?

$>$ What aspects of the school did you like or dislike?

$>\quad$ Who came to the school?

$>$ Did you decide by yourself or your parents tell you to do?

$\checkmark \quad$ What kind of Japanese cultural events have you taken part in? and why?

$>$ How did you participate in the events? As a volunteer or participant?

$>\quad$ What did you do in the events?

$\checkmark \quad$ Have you taken your children to cultural events?

$\checkmark$ Do you participate in Japanese community events?

$\checkmark \quad$ Have you ever been to Japan?

$>\quad$ With whom? By yourself, with your family, with your friend?

$>$ For what? Travel, visiting a relative, study, or other reasons?

$>$ What did you do in Japan?

$>\quad$ What was the most impressive experience in Japan?

$>$ How did local Japanese people treat you?

Family now

$\checkmark \quad$ Where have you lived in your life?

$\checkmark \quad$ Why did you come to Toronto and stay here?

$\checkmark \quad$ Could you describe your current neighborhood?

$>$ What traditions or customs have you made an effort to preserve? Why?

$\checkmark \quad$ What language do you use in your family?

$\checkmark \quad$ What holidays does your family celebrate?

$>$ Are there any traditional foods served on a specific day?

$\checkmark$ Do you have relatives close to your house or/and in Japan?

$>$ Where do they live?

$>$ How often do you contact them?

$\checkmark \quad$ Does your family hold reunions? Or Do you have any specific day when all the family get together?

$>$ When? Where? Who attends?

$>$ How long have the reunions been going on?

$>$ What activities take place?

$>$ How has the reunion changed?

$\checkmark \quad$ What language do you use when you communicate with your family?

$\checkmark$ What traditions do you want to pass down to your children?

Career

$\checkmark \quad$ What was your first job? 
$>$ How did you get your first job? What was it like to look for a job in those days?

$\checkmark \quad$ What challenges did you face in job hunting? Or in working for a company?

$\checkmark \quad$ What kind jobs have you had in your life?

$\checkmark \quad$ What is your favorite job?

\section{Friendship}

$\checkmark \quad$ Who are your close friends now?

$>$ How did you meet them?

$\checkmark \quad$ Have you heard any stories like that from your relatives, families, or friends?

$\checkmark$ How do you meet a new friend(s) recently?

Marriage and Love

$\checkmark \quad$ How did you get to know your partner?

$\checkmark$ What was the expectation of your family about your marriage? 


\section{Reference}

Alonso, A. M. (1988). The effects of truth: Re-presentations of the past and the imagining of community. Journal of Historical Sociology, 1(1), 33-57. doi:10.1111/j.14676443.1988.tb00003.x

Ashmore, R. D., Deaux, K., \& McLaughlin-Volpe, T. (2004). An organizing framework for collective identity: Articulation and significance of multidimensionality. Psychological Bulletin, 130(1), 80-114. doi:10.1037/0033-2909.130.1.80

Atkinson, P., \& Delamont, S. (2006). Rescuing narrative from qualitative research. Narrative Inquiry, 16(1), 164-172. doi:10.1075/ni.16.1.21atk

Bevernage, B. (2010). Writing the past out of the present: History and the politics of time in transitional justice. History Workshop Journal, 69(69), 111-131. doi:10.1093/hwj/dbq008

Block, S., \& Galabuzi, G. (2011). Canada's colour coded labour market: The gap for racialized workers Canadian Centre for Policy Alternatives $=$ Centre Canadien de politiques alternatives.

Caruthers, L. (2005). The unfinished agenda of school desegregation: Using storytelling to deconstruct the dangerous memories of the American mind. Educational Studies, 37(1), 24-40. doi:10.1207/s15326993es3701_4

Chou, C. (2008). Critique on the notion of model minority: An alternative racism to Asian American? Asian Ethnicity, 9(3), 219-229. doi:10.1080/14631360802349239

Clandinin, D. J. (2006) "Narrative inquiry: A methodology for studying lived experience." Research studies in music education 27, (1): 44-54.

Creswell, J. W. (2012). Qualitative inquiry and research design: Choosing among five approaches. Sage.

Conway, B. (2010). New directions in the sociology of collective memory and commemoration: Sociology of collective memory and commemoration. Sociology Compass, 4(7), 442-453. doi:10.1111/j.1751-9020.2010.00300.x

Dellios, A. (2015). Commemorating migrant camps: Vernacular memories in official spaces. Journal of Australian Studies, 39(2), 252-271. doi:10.1080/14443058.2015.1018922

Dick, L. (2010). Sergeant Masumi Mitsui and the Japanese Canadian war memorial: Intersections of national, cultural, and personal memory. Canadian Historical Review, 91(3), 435-463. doi:10.3138/chr.91.3.435

Domingues, J. M. (1997). Social memory, social creativity and collective subjectivity. Social Science Information, 36(3), 469-492. doi:10.1177/053901897036003004

Duval, D. T. (2004). Linking return visits and return migration among Commonwealth Eastern Caribbean migrants in Toronto. Global networks, 4(1), 51-67.

Essers, J. (2012). "Re-writing the organization: the ideological deadlock of narrative methodology." Journal of Organizational Change Management, 25, 332-351.

Fraser, H. (2004). "Doing narrative research analysing personal stories line by line." Qualitative Social Work, 3 (2), 179-201. 
Fujiwara, A. (2012). Japanese-Canadian internally displaced persons: Labour relations and ethno-religious identity in southern alberta, 1942-1953. Labour/Le Travail, (69), 63.

Gedi, N., \& Elam, Y. (1996). Collective memory — what is it? History and Memory, 8(1), $30-50$.

Gentles, S. J., Charles, C., Ploeg, J., \& McKibbon, K. A. (2015). Sampling in qualitative research: Insights from an overview of the methods literature. The Qualitative Report, 20(11), 1772.

Goutor, D. (2007). Guarding the gates: The canadian labour movement and immigration, 1872-1934 UBC Press.

Hall, S., Morley, D., \& Chen, K. (1996). New ethnicities. In Stuart Hall: Critical dialogues in cultural studies (pp. 442-451). London: Routledge.

Iino, M. (1985). Nichiei Tsūshō Kōkai Jōyaku to Kanada no Nihonjin Imin Mondai [AngloJapanese Treaty of Commerce and Navigation and Immigration issues in Canada]. Kokusai Seiji, 1985(79), 1-18.

Isin, E. F., \& Turner, B. S. (2007). Investigating citizenship: an agenda for citizenship studies. Citizenship studies, 11(1), 5-17.

Izumi, M. (2001). Reconsidering ethnic culture and community: A case study on Japanese Canadian Taiko drumming. Journal of Asian American Studies, 4(1), 35-56.

Izumi, M. (2008) "Hyakunengo kara Mita Banku-ba- Bōdō [Vancouver riot seen from 100 years later]." Ritumeikan Gengo Bunka Kenkyu 20.1 (2008): 215-235.

Izumi, M. (2013). Tetsujōmō Naki Kyōsei Shūyōjo [Concentration Camp without Barbed Wire]. Ritumeikan Gengo Bunka Kenkyu, 25(1), 119-135.

Kamo, H. (2010). Post Ridoresuki no "Nikkei Komyunity" to Nihonjin Ijusha [Post-Redress "Nikkei Community" and Japanese immigrants]. Imin Kenkyu, 6, 1-22.

Keddell, E. 2009. "Narrative as identity: Postmodernism, multiple ethnicities, and narrative practice approaches in social work." Journal of Ethnic \& Cultural Diversity in Social Work, 18 (3), 221-241.

Keightley, E. (2010). Remembering research: Memory and methodology in the social sciences. International Journal of Social Research Methodology, 13(1), 55-70. doi:10.1080/13645570802605440

Kelley, N., \& Trebilcock, M. J. (2010). The making of the mosaic: A history of canadian immigration policy University of Toronto Press.

Kobayashi, A. (1992). Japanese-canadian redress settlement and its implications for ’race relations. Canadian Ethnic Studies Journal, 24(1), 1.

Kobayashi, A. (2002). New worlds, new lives: Globalization and the people of Japanese descent in the Americas and from Latin America in Japan (pp. 205-220) (R. Hirabayashi-Lane, A. Kikumura-Yano, \& J. A. Hirabayashi, Authors). Stanford: Stanford university press.

Lindsay, C. 2007. The Japanese Community in Canada Profiles of Ethnic Communities in Canada. 2001 Census of Canada. Statistics Canada Catalogue no. 89-621-XIE. 
Ottawa, Ontario. http:/www.statcan.gc.ca/pub/89-621-x/89-621-x2007013-eng.pdf (accessed September 12, 2016)

Löfström, J. (2011). Historical apologies as acts of symbolic inclusion - and exclusion? reflections on institutional apologies as politics of cultural citizenship. Citizenship Studies, 15(1), 93-108. doi:10.1080/13621025.2011.534933

Makabe, T. (1998). The Canadian Sansei, University of Toronto Press.

Makabe, T. (2005). Intermarriage: Dream becomes reality for a visible minority? Canadian Ethnic Studies Journal, 37(1), 121.

Marsh, J. M. (2012, February 23). Japanese Internment: Banished and Beyond Tears. Retrieved August 17, 2016, from http://www.thecanadianencyclopedia.ca/en/article/japanese-internment-banishedand-beyond-tears-feature/

Miki, R. (2000). Altered states: Global currents, the spectral nation, and the production of "Asian canadian". Journal of Canadian Studies/Revue d'Études Canadiennes, 35(3), 43.

Miki, R. (2004). Redress: Japanese Canadians in negotiations. Raincoast Books.

Miki, R. (2005). Turning In, Turning Out: The Shifting Formation of "Japanese Canadian" from Uprooting to Redress. In J. Lee \& J. S. Lutz (Eds.), Situating "race” and racisms in time, space, and theory: Critical essays for activists and scholars (94113). McGill-Queen's University Press.

Minamikawa, B. (2015). "Zaibei Nikkeijin/ Zaigai Nihonjin de Arukoto" no Gendaiteki Imi [The Meaning in contemporary society to be "Nikkeijin in the United States/Japanese out of Japan"]. Ritumeikan Gengo Bunka Kenkyu, 17(1), 137-143.

Nora, P. (1989). Between memory and history: Les lieux de mémoire. Representations, 26(1), 7-24. doi:10.1525/rep.1989.26.1.99p0274v

Noro, H. (2009). The role of Japanese as a heritage language in constructing ethnic identity among hapa Japanese canadian children. Journal of Multilingual and Multicultural Development, 30(1), 1-18. doi:10.1080/01434630802307874

Oharazeki, K. (2013). Listening to the Voices of "Other" Women in Japanese North America: Japanese Prostitutes and Barmaids in the American West, 1887-1920. Journal of American Ethnic History, 32(4), 5-40.

Oikawa, M. (2012). Cartographies of violence: Japanese canadian women, memory, and the subjects of the internment University of Toronto Press.

Olick, J. K., \& Robbins, J. (1998). Social memory studies: From" collective memory" to the historical sociology of mnemonic practices. Annual Review of sociology, 105-140.

Olick, J. K. (2009). Between chaos and diversity: Is social memory studies a field? International Journal of Politics, Culture, and Society, 22(2), 249-252. doi:10.1007/s10767-009-9059-7

Omatsu, M. (1992). Bittersweet passage: Redress and the Japanese canadian experience Between The Lines. 
Patton, M. Q. (2002). Two decades of developments in qualitative inquiry: A personal, experiential perspective. Qualitative Social Work, 1 (3), 261-83.

Peterson, E. E., \& Langellier M. K. 1997. "The politics of personal narrative methodology." Text and performance Quarterly 17 (2): 135-152.

Russell, N. (2006). Collective memory before and after Halbwachs. The French Review, 79(4), 792-804.

Sangster, J. (1994). Telling our stories: Feminist debates and the use of oral history. Women's History Review, 3(1), 5-28. doi:10.1080/09612029400200046

Sarkowsky, K. (2008). Nisei negotiations: Citizenship and the nation in Japanese Canadian writing. West Coast Line: A Journal of Contemporary Writing \& Criticism, 42(3), 28 .

Stevenson, N. (2003). Cultural citizenship in the 'cultural' society: A cosmopolitan approach. Citizenship studies, 7(3), 331-348.

Sugiman, P. (2004). Memories of internment: Narrating Japanese Canadian women's life stories. The Canadian Journal of Sociology / Cahiers Canadiens De Sociologie, 29(3), 359-388. doi:10.1353/cjs.2004.0049

Sugiman, P. (2006). Unmaking a Transnational Community: Japanese Canadian Families in Wartime Canada. In L. L. Wong \& V. Satzewich (Authors), Transnational identities and practices in Canada (pp. 52-68). Vancouver: UBC Press.

Sugiman, P. (2009). "Life is sweet": Vulnerability and composure in the wartime narratives of Japanese Canadians. Journal of Canadian Studies/Revue d'Études Canadiennes, 43(1), 186-218.

Syed, M., \& Azmitia, M. (2008). A narrative approach to ethnic identity in emerging adulthood: Bringing life to the identity status model. Developmental Psychology, 44(4), 1012-1027. doi:10.1037/0012-1649.44.4.1012

Tsuda, T. G. (2012). Diasporas without a consciousness Japanese Americans and the lack of a Nikkei identity. Regions \& Cohesion, 2(2), 83. doi:10.3167/reco.2012.020205

Tsuda, T. (2014). "I'm American, not Japanese!”: The struggle for racial citizenship among later-generation Japanese Americans. Ethnic and Racial Studies, 37(3), 405-424. doi:10.1080/01419870.2012.681675

Tsuda, T. G. (2015). Recovering heritage and homeland: Ethnic revival among FourthGeneration Japanese Americans. Sociological Inquiry, 85(4), 600-627. doi:10.1111/soin.12095

Tupper, J. (2002). Silent voices, silent stories: Japanese Canadians in social studies textbooks. Alberta Journal of Educational Research, 48(4), 327.

Wertsch, J. V., \& Roediger, H. L. (2008). Collective memory: Conceptual foundations and theoretical approaches. Memory, 16(3), 318-326. doi:10.1080/09658210701801434

Wood, A. L. (2013). Challenging history: Public education and reluctance to remember the Japanese Canadian experience in British Columbia. Historical Studies in Education, 25(2), 65. 
Yamada, C. (2001). Banku-ba- ni Okeru Nikkei Imin no Katsudō to Rentai [Activities and Solidarity of Nikkei Immigrants in Vancouver]. Nagasaki Kenritu Daigaku Ronshū, 35 (3), 121-150 